\title{
A Qualitative Study on Voice Care related to Performance, Voice Problems and Voice Knowledge in Professional Singers
}

\author{
Sang Hee Park ${ }^{a, b}$, Seong Hee Choi ${ }^{a, c}$ \\ ${ }^{a}$ Graduate program in Audiology \& Speech-Language Pathology, Daegu Catholic University, Gyeongsan, Korea \\ ${ }^{b}$ Department of Music \& Arts, Gyeongju University, Gyeongju, Korea \\ 'Department of Audiology and Speech-Language Pathology, College of Bio and Medical Sciences, and Catholic Hearing Voice Speech Center, \\ Daegu Catholic University, Gyeongsan, Korea
}

\author{
Correspondence: Seong Hee Choi, $\mathrm{PhD}$ \\ Department of Audiology and Speech-Language \\ Pathology, Institute of Biomimetic Sensory Control, \\ and Catholic Hearing Voice Speech Center, Daegu \\ Catholic University, 13-13 Hayang-ro, Hayang-eup, \\ Gyeongsan 38430, Korea \\ Tel: $+82-53-850-2542$ \\ Fax: +82-53-359-6780 \\ E-mail: shgrace@cu.ac.kr
}

Received: October 20, 2020

Revised: December 8, 2020

Accepted: December 23, 2020

\begin{abstract}
Objectives: Although singers are elite voice users who strive to keep their voice healthy for their performances, they are at high risk for voice problems. Understanding of professional singers' voice care and their knowledge about voice is the basis for educating about voice care and preventing voice disorders that may interfere with daily activities and performance. The purpose of this study was to investigate voice care related to performance, voice problems, and voice knowledge in singers. Methods: A total of 10 classical singers (5 males and 5 females) who had more than 10 years of experience in playing and actively performing as opera singers and specialized in using their voice for more than five hours a week participated. The interview content was randomly selected and coded, and the rest of the transcripts were coded by two language pathologists. Results: 4 top topics and 10 sub- topics were derived: Voice care $\&$ habits before, during, and after a performance as well as in daily life \& periods where they had sore throats; and knowledge of voice anatomy \& physiology and singing voice. Conclusion: This study suggests that professional singers are always trying to manage their voice. However, they rely on their personal experiences or vocal teachers when they have voice problems. In addition, singers showed insufficient knowledge of voice anatomy \& physiology, and little experience with voice therapy. Vocal hygiene and voice health education would be useful to prevent voice problems and maintain their healthy singing \& speaking voice.
\end{abstract}

Keywords: Voice Care, Voice Knowledge, Voice Disorders, Voice Therapy, Singers, Qualitative Study
성악가는 전문적인 공연의 음성 조건을 충족시키기 위해서 오랜 기간에 걸쳐 건강한 목소리 이상의 최상의 호흡, 공명, 발성, 조음을 습득하기 위해 훈련한다. 공연 예술가들은 대부분 유년기에 교육 과 훈련을 시작하며, 공연 예술 전공자로서 평생동안 기술을 다듬 는다. 하지만, 공연과 관련된 손상이나 부적절한 발성 테크닉으로 인한 음성 외상, 공연과 관련된 불안이나 정서적 스트레스 등을 곆 을 위험이 높다(Leah \& Jayme, 2018). Phyland, Oates와 Greenwood (1999)에 의하면 성악가들은 다른 직업적 음성 사용자에 비 해 높은 음성장애율을 보였으며, 성악가의 $69 \%$ 가 음성 문제를 경
험하였다고 보고하였다. Weekley, Carroll, Korovin과 Fleming (2017)의 연구에서는 성악가들이 겪는 가장 일반적인 음성 증상은 근육의 긴장이었고, 음성 상실, 음역 감소, 노래를 작게 혹은 크게 부르는 데 어려움, 쉰 목소리, 음성 피로를 보고하였으며, 이들 중 $69 \%$ 가 음성 문제가 12 개월 이상 지속되었다고 보고하였다. Tepe 등(2002)도 젊은 합창 가수들의 $56 \%$ 가 음성 문제를 경험하였다고 하였다. 최근 Santos 등(2019)의 연구에서도 여성 실용 음악가들은 알레르기 비염과 관련된 호흡기계의 문제가 높게 나타났으며, 남성 실용 음악가들 집단에서는 유의하게 알코올 섭취가 많았다고 보고 
하였다. 특정한 행동이나 유형의 음성 사용은 음악의 장르에 따라 달라지기도 하는데, 남들이 노래하는 모습을 흉내 내거나 심지어 는 자신의 성구 밖의 음역에서 노래를 부르기도 하며, 이러한 음성 행동은 음성의 과부하와 음성 외상(phonotrauma) 및 불완전한 성 문폐쇄의 원인이 된다(Carroll et al., 2006).

호흡 기능은 성악가에게 필수적인데, 클래식 성악가들은 긴 구 절을 부르면서 대부분의 폐활량을 사용할 수 있으며 다른 장르의 성악가보다 낮은 후두 위치로 성문폐쇄를 더 효율적으로 조절할 수 있다(Cleveland, 1994). 또한, 성악가들은 자신의 발성 기관에 대한 높은 고유수용성 감각을 가지고 있기 때문에 성도의 변화나 손상에 대한 약간의 변화에 대해서도 잘 지각할 수 있다. Carroll 등(2006) 은 7명의 성악가를 대상으로 조사한 결과, 성악가들은 적어도 공연 전 48시간의 음성 휴식을 한 경우, 공연 후에 작은 목소리를 내는 어려움이나 큰 목소리의 노력성 발성이 감소하였고 음성 피로도 유 의하게 감소하는 것으로 보고하였다. 이처럼 공연 전후 음성 관리 는 성악가의 음성 문제와 밀접한 관련이 있다. 또한, Braun-Janzen 과 Zeine (2008)은 129 명의 가수들을 대상으로 성대 기능에 대한 지식과 관심의 정도에 대해 설문조사를 실시하였는데, 성악 경험이 많은 전문적 성악가들이 아마추어 성악가들에 비해 발성의 해부 및 생리, 음성 위생, 기능적 음성장애에 대한 이해 수준이 훨씬 더 높은 것으로 나타났다. 하지만, 음성장애를 전문으로 하는 언어재 활사를 대상으로 직업적 음성 사용자에 관한 질적연구에 따르면, 성악가들은 의외로 음성 위생(vocal hygiene)이나 발성 기전에 대 해 잘 모르는 경우도 있었다(Pyo, 2011a). 나아가 성악가들은 효율 적이고 안전한 음성 사용법에 대해 높은 관심을 가지고 있음에도 불구하고, 그들의 음성 치료에 대한 이해와 전반적인 음성 지식이 부족하다고 보고되었다(Braun-Janzen \& Zeine, 2008). 이러한 연 구결과들을 종합해 볼 때, 성악가들이 발성에 대한 이론과 실제에 대해 얼마나 이해하고 인식하고 있는지에 대한 연구는 연구자마다 차이가 있다. 현재까지 직업적 음성 사용자인 성악가의 음성 문제 에 대한 질적연구는 양적 연구에 비해 매우 부족하며(Jeon, Kim, \& Yoo, 2018; Kim \& Yoo, 2017; Moon \& Chung, 1998; Pyo, 2011a), 국 내에서 전문 성악가를 면담자로 인터뷰를 시행한 질적연구는 전무 한 실정이다.

전문 성악가들의 음성 관리와 목소리에 대한 지식의 이해는 그 들의 음성 관리를 교육하고 일상 활동과 공연에 지장을 줄 수 있는 음성장애를 예방하는 기초가 된다. 이에 본 연구는 전문 오페라 성 악가와의 심층 면담을 통해 성악가들의 공연 및 음성장애와 관련 된 음성 관리 실태와음성 지식 정도에 대해 살펴보고자 한다.

\section{연구방법}

\section{연구 참여자}

본 연구를 위해 선발된 면담자들은 국내외에서 활발히 오페라 가수로 연주 활동을 하고 있는 전문 성악가 총 10 명(남 5 명, 여 5명) 이며, 연령은 32-37세(평균 연령 34.5 \pm 3.1 )이었다. 본 연구자가 세 운 면담자는 타당도, 신뢰도, 본 연구자와 면담자의 편향을 통제하 기 위하여 다음과 같은 6 개 기준을 모두 포함하는 자로 선발하였 다. 첫째, 전문 성악가 중 오페라 가수로 활동하는 자로 선정하였다. 그 이유는 오페라 가수는 콘서트 또는 오케스트라 협연 위주의 활 동을 하는 성악가와 비교했을 때 음성 사용량에서 확연한 차이가 있다. 국내에서 공연되는 오페라는 약 2 시간 동안 진행된다. 오페라 가수는 그 긴 시간 동안 최상의 음성과 컨디션을 관리해야 하며, 노 래를 하면서 동시에 연기를 하거나 춤을 춰야 한다. 뿐만 아니라, 오 페라의 반주는 대부분 45 인조 이상의 오케스트라가 담당한다. 마 이크 사용 없이, 오케스트라의 소리를 능가하는 공명과 발성을 산 출하고, 또 말하는 듯이 대사를 해야 하는 이러한 오페라 가수의 음성 및 에너지 사용량은 칼로리로 간음할 수 없을 정도의 소비임 에 틀림없다. 둘째, 면담자를 타. 동일전공의 학사 편입을 한 자나 석사학위부터 성악과를 전공한 자와 차별화하기 위하여 4년제 대 학교 성악과를 졸업한 자로 제한하였다. 셋째, 국내 대학교의 학사 과정 커리큘럼으로는 4년 동안 오페라를 공연할 수 있는 기회가 극 히 드물기 때문에, 본 연구에서는 면담자를 성악과 석사 이상의 학 위를 취득한 자로 제한하였다. 넷째, 국내와 국외의 성악 교육 및 커 리큘럼을 경험한 자를 선정하기 위하여 면담자를 해외 유학 경험 및 해외 학위 취득자로 제한하였다. 해외 학위의 국가명은 편향되 지 않게 하기 위하여 다양한 국가에서 유학한 성악가를 섭외하였 다. 다섯째, 주 5 시간 이상 성악하는 데 목소리를 사용하고, 성악을 가르치는 자로 제한하였다. 본 면담은 코로나 19로 인하여 전화 통 화로 이루어지므로, 연구의 일반화를 제한하는 지리적 한계를 예 방하기 위하여 다양한 지역에서 거주하며 전문적 성악 활동을 하 는 자로 섭외하였다. 선발 기준에 따른 최종 면담자의 기본 정보는 Table 1과 같다.

\section{자료수집 및 연구절차}

\section{면담 질문지 개발}

본 연구의 설문 초안은 국내 성악과에서 학사와 석사, 미국에서 성악과 박사학위를 소지하였으며, 전문 성악가로 연주 경력이 10년 이상이며, 언어치료 박사과정에 재학 중인 제 1 저자가 성악가의 음 성 치료(Lee \& Yoo, 2016), 인터뷰를 통한 성악가의 음성 연구(Pyo, 
Table 1. Information of participants

\begin{tabular}{lcccccc}
\hline $\begin{array}{c}\text { Partici- } \\
\text { pants }\end{array}$ & $\begin{array}{c}\text { Voice } \\
\text { classification }\end{array}$ & Residence & Degree & $\begin{array}{c}\text { Degree } \\
\text { country }\end{array}$ & $\begin{array}{c}\text { Musical } \\
\text { career } \\
\text { (yr) }\end{array}$ & $\begin{array}{c}\text { Voice use } \\
\text { time/ } \\
\text { week (hr) }\end{array}$ \\
\hline S1 & F/Soprano & Kyoungnam & MM & Estonia & 17 & 15 \\
S2 & F/Soprano & Incheon & TPAC & Italy & 16 & 10 \\
S3 & F/Soprano & Seoul & MM & U.S.A & 13 & 9 \\
S4 & F/Mezzo soprano & Kangwon & TPAC & Italy & 16 & 16 \\
S5 & F/Mezzo soprano & Seoul & MM & U.S.A & 13 & 40 \\
S6 & M/Tenor & Pusan & MM & Germany & 12 & 28 \\
S7 & M/Baritone & Pusan & MM & Italy & 16 & 30 \\
S8 & M/Baritone & Pusan & DMA & Germany & 16 & 35 \\
S9 & M/Bass & Kyoungnam & MM & Russia & 18 & 31 \\
S10 & M/Bass & Pusan & MM & Italy & 14 & 56 \\
\hline
\end{tabular}

MM= Master of Music; TPC= Top Performing Arts Course; PhD= Doctor of Philosophy; DMA=Doctor of Musical Arts.

2011a, 2011b), 설문지를 통한 성악가의 음성 연구(Braun-Janzen \& Zeine, 2008; Jun et al., 2018; Kang, Kim, \& Yoo, 2018; Weekly et al., 2018), 문헌 연구를 통한 성악가의 음성 연구(Kim \& Yoo, 2017; Shin, 2004) 및 Garcia와 Lopez (2017)의 성악가의 음성 습관을 위 한 자가 보고 설문지(self-report Questionnaire for Singers on Voice Habits, Q-SinVocHab)의 국외 연구를 참고하여 현장에서 경험을 바탕으로 본 연구의 목적과 방법에 따라 재구성하였다. 면담 질문 지를 구성하면서 고려했던 문항 구성의 원칙은 다음과 같다. 첫째, 음성 위생, 음성장애, 음성 산출에 관련된 지식이나 음성장애 치료 행위에 관련된 문항은 성악가들이 이해하기 쉬운 용어로 문항을 구성한다. 둘째, 질문은 중복되지 않고 간결하며, 현장 전문가의 의 견을 반영하여 핵심 내용이 포함되도록 구성 한다. 셋째, 각 문항의 핵심을 효과적으로 전달하여 이해를 용이하게 하고 정확한 정보를 수집하고자 문항의 핵심 어휘를 밑줄을 그어 강조하였다. 개발된 면담 질문지는 10 년 이상의 임상 및 교육 경험이 있는 언어치료학 과 교수 1 인과 20 년 경력의 교육 경험과 공연 경험이 있는 성악과 교 수 1 인에게 검토하여 내용타당도를 검증받았고, 피드백에 따라 다 음과 같은 내용을 반영하여 면담 질문지를 제작하였다. 면담 질문 지 수정 과정에서 이해가 어렵거나 모호한 질문은 내용을 구체화 하거나 이해하기 쉬운 용어로 제시하였으며, 심층 연구를 위해 경 험이나사례에 대한 예시에 대한 질문을 추가할 수 있도록 하였다.

\section{예비연구 및 면담 질문지 수정}

개발된 예비 면담 질문지를 바탕으로 1 차 예비 연구를 실시하였 다. 10 년 이상의 성악 공연 경력을 가지고 현재 성악 교사로 일하고 있는 오페라 성악가 1 인에게 심층 면담을 실시하였다. 면담 질문이
Table 2. Topics and subtopics derived from analysis

\begin{tabular}{|c|c|}
\hline Main topics & Sub-topics \\
\hline $\begin{array}{l}\text { Voice care and habits in ordi- } \\
\text { nary time }\end{array}$ & $\begin{array}{l}\text { Voice care } \\
\text { Diet habits } \\
\text { Exercise and other habits }\end{array}$ \\
\hline $\begin{array}{l}\text { Voice care and habits before, } \\
\text { during, and after a perfor- } \\
\text { mance }\end{array}$ & $\begin{array}{l}\text { Voice care } \\
\text { Diet management }\end{array}$ \\
\hline $\begin{array}{l}\text { Voice care and habits when } \\
\text { throat hurts }\end{array}$ & $\begin{array}{l}\text { Voice care } \\
\text { Diet management } \\
\text { Awareness of medical treatment \& voice therapy }\end{array}$ \\
\hline Voice Knowledge & $\begin{array}{l}\text { Understanding of anatomy \& physiology for voice } \\
\text { production } \\
\text { Understanding of singing voice }\end{array}$ \\
\hline
\end{tabular}

나 전문 용어를 잘 이해하지 못하는 경우, 용어를 이해하기 쉬운 용 어로 수정하였다. 질문 내용 중 성악가의 평상시와 공연 중 음성 습 관과 관리가 다를 수 있어 문항의 질문을 두 가지로 분리하여 설문 내용을 수정 보완하였다. 음성 지식과 산출에 대한 질문 중 성종에 대한 질문은 중요한 부분이라는 지적에 따라 질문 내용에 추가하 였다. 이에 해당 내용을 추가 반영하여 질문지를 수정한 후 최종 면 담지에 대한 내용 타당도를 검증하였다. 내용 타당도는 초안의 내 용을 검토한 언어치료학과 전공 교수 1 인과 성악가 1 인의 확인을 거 쳤으며, 최종 면담 질문지의 주요 내용은 Table 2에 제시하였다.

\section{면담 및 전사 절차}

본 연구의 면담은 2020년 7월 1일부터 8월 31일까지 이루어졌으 며, 면담 내용과 반응의 일관성을 위해 모든 면담은 제 1 저자에 의해 개별 혹은 전화 인터뷰를 통해 진행되었다. 전화 면담 시 사전에 전 화로 면담을 의뢰하였고, 면담자가 가능한 시간에 전화로 면담을 진행하였다. 그리고 면담 의뢰 시, 개인정보는 유출하지 않겠다는 구두 서약을 하였으며, 면담 내용의 녹음과 전사, 제 1 저자외 한 명 의 동행 조사자(전문 성악가), 두 명의 전사 확인자(언어재활사 1 급, 2 급 소지자 각 1 명)에 대한 동의를 구하였다. 본 연구의 제 1 저자는 국내 성악과에서 학사와 석사, 성악과 박사 학위 소지자로 면담자 의 음악적 용어와 발성을 묘사하는 은어를 정확하게 이해하고 해 석할 수 있었으며, 정확한 내용 전달을 위해 내용의 의미가 애매모 호한 경우 재질문을 통해 의미를 확인하면서 면담을 진행하였다. 모든 질문은 제 1 저자와 면담자의 편향을 통제하기 위해 개방형으 로 간결하게 시행하였으며, 면담자의 인터뷰 내용이 투명하지 않을 경우 확인 질문을 하며 정확한 의미 전달과 의미 이해를 돕고자 하 고자 하였다. 면담 내용은 삼성 갤럭시 $\$ 20$ 의 음성 녹음을 사용하 였으며, 면담은 면담자 당 평균 39 분 72 초(30분 10 초- 48 분 58 초) 동 
안 진행하였다. 면담 전사 결과는 Pyo (2011a)의 질적연구 분석 방 법을 참고하여 A4용지, 글자 크기 10 , 문단 간격 $160 \%$ 기준으로 평 균 25.4장(17-35장), 총 254장이었다.

\section{면담 분석}

면담 내용 분석은 본 연구자가 무작위로 하나의 전사본을 선정 하여 코딩하고 그에 따라 나머지 9 개의 전사본을 코딩하였다. 면담 주제에 대한 귀납적 추론 방법을 사용하여 정확한 분석 결과를 도 출하고자 하였다.

\section{타당도와 신뢰도}

본 연구는 질적연구의 타당도를 높이기 위하여 제 1 저자 본인 스 스로의 편견을 최소화하기 위한 조치로 전문 성악가 조사자 1 명을 면담자의 인터뷰에 동반 시켰고 전화 인터뷰시 조사자 1 명은 스피 커 폰으로 같이 듣도록 하였다. 조사자와 인터뷰 내용을 함께 듣고, 본 연구자와 조사자가 각각 전사를 하고, 그 전사를 함께 비교하며 코딩을 하였다. 면담 전사는 본 연구자와 면담에 동행한 조사가가 각각 전사하였다. 전사 자료 확인은 본 연구의 신뢰도를 높이기 위 하여 조사자 삼각측정법을 사용하였다. 즉, 본 연구자와 면담자, 그 리고 이해관계가 없는 언어재활사 2 명이 시행하여 동료 검증을 실 시하였다. 최종 전사와 분석 확인 후, 연구자 내의 평가를 시행하였 고, 모두의 동의가 있을 때까지 수정 - 보완 하였다. 마지막으로 면담 자들에게 전자 우편으로 결론을 공유하여 확인을 의뢰하였고, 모 든 면담자의 확인 회신을 받았다.

\section{연구결과}

\section{평상 시 음성 관리 및 습관}

\section{음성 관리}

오페라 성악가들인 면담자들은 평상시에도 음성을 관리하려고 노력하는 것으로 나타났다. 주로 음성 휴식(voice rest)이나 가글링, 큰 소리 내지 않기와 같은 음성 위생(vocal hygiene)에 초점을 두었 다. 노래를 부르거나 공연 때가 아니더라도 입술트릴이나 허밍과 같 은 발성 워밍업, 이완, 스트레칭과 같은 발성 전 준비 단계로 목의 상 태를 점검하고 신경을 쓰고 있음을 확인하였다.

말을 안 하려고 노력하고 있습니다. 큰 소리를 내지 않는 방법 또한 많이 하고 있습니다. 평상시 발성 워밍업은 1 시간 이요..... 아, 에, 이, 오, 우, 허밍으로 합니다. $(\mathrm{S} 1,2,17)$

저는 20 분 정도 하는 것 같습니다. 립 트릴이랑 ‘튀’라는
걸로 발성을 하고 있습니다. 큰 소리를 내거나 그렇게 하지 않고, 목에 많이 부담이 안 간다고 생각해서 호흡을 실어서 많이 말을 하는 것 같습니다. 발성 워밍업을 하기 전에 턱이 나 근육을 풀기 위해서 스트레칭을 많이 하고, 혀에 힘이 들어가 있다든가 그런 경우에는 허밍이라든가 혀를 풀어줄 수 있는 그런 걸 하고요. $(\mathrm{S} 3,2)$

발성 워밍업을 무조건 합니다. 한 시간을 연습을 한다 치 면, 발성 워밍업을 40 분, 노래를 20 분합니다. 피아노 앞에 서서 스케일을 계속 빠르게 발성 워밍업을 해서 몸에 힘이 안 들어가게끔 연습을 하고 있습니다. (S6, 4)

저는 가글링을 매일 하거든요. 매일 저녁 미지근한 물에 굵은 소금을 섞어서 한 시간 반에서 두 시간 가글을 하면서 발성 워밍업을 합니다. $(\mathrm{S} 7,4)$

오전에 눈 뜨면 발성 워밍업 먼저 해보고 그리고 하루 일 과를 시작합니다. 간단하게 허밍으로 해서 15 분, 20 분 정도 발성 워밍업을 합니다. $(\mathrm{S} 8,4)$

큰 소리를 지르지 않으려고 하고, 정확한 발성으로 소리 를 내려고 노력하고요. 발성(워밍업)은 한 5 분 10 분? 모음 연습하고 스케일 연습을 하죠. 몸이 깨야 성대도 풀리기 때 문에 샤워를 제일 먼저 합니다. 그리고나서 허밍이나 목을 조금 간단하게 풀수 있을 정도로 풀어놓고 그 다음에 음성 을 많이 사용하는 편입니다. 그리고 복식 호흡을 바탕으로 말을 하려고 합니다. (S10, 3,7)

\section{식이 습관}

면담자들은 대부분 목소리에 영향을 주는 음식물에 대해 인지 하고 있었으며, 목소리에 나쁜 영향을 주는 식사 패턴은 피하고 있 는 것으로 나타났다. 평상시에도 성대의 수분을 유지하는 것을 중 요시하였다. 커피와 같은 카페인 음료를 섭취하고 있었으나, 동시에 술이나 헛기침을 유발할 수 있는 유제품 섭취를 제한하였으며 수분 섭취를 하여 성대를 건조하지 않도록 관리하고 있음이 나타났다. 알레르기 비염이나 인후두역류(laryngopharyngeal reflux, LPR)가 목소리에 미치는 영향에 대해 인지하고 있었으며, 이를 위해 음식 물 섭취에 주의를 기울이고 있었다. 하지만, 개인에 따라서는 본인 의 취향이나 기호에 따라 야식이나 고기를 주로 섭취하는 경향을 보이기도 하였다. 특히, 야식이나 매운 음식물은 역류성 후두염과 같은 기능적 음성장애를 초래할 수 있으므로 전문 성악가들에게 도 이러한음성 위생의 재교육의 필요성이 나타났다.

물을 많게는 $1.5 \mathrm{~L}$ 정도 마시고 있습니다. 카페인이나 알 
코올을 섭취하면 목에 무리가 와서 먹지 않고 있습니다. 유 제품을 먹었을 때는 이물감이 많아서 먹지 않고 있고, 매운 음식은 즐겨 먹는 편입니다. 가끔씩 자극은 되지만 목이 좀 시원한 느낌도 있습니다. 짠 음식은 좋아하지 않습니다. 저 는 야식을 즐기는 편이라 저녁 늦게도 먹을 때가 많습니다. 한 10시? 11시? 치킨과 과일을 먹습니다. (S1, 3, 4).

밤늦게 역류성 식도염을 유발하는 음식을 먹지 않으려 고 그것만주의하는 것 같습니다. (하루에 물은) 500미리 정 도 $\cdots .$. (중략) $\cdots$ 커피를 먹습니다. 한 세 네 잔 정도요? 디카 페인으로 먹습니다. 역류성 식도염이 유발되었을 때 많이 불편하더라고요. $(\mathrm{S} 2,3,4)$

하루에 물은 1.5 에서 $2 \mathrm{~L}$ 정도 먹는 것 같습니다. 커피는 하루에 아메리카노를 한잔 마시고 있습니다. 술은 잘 안 마 시려고 노력합니다. $(\mathrm{S} 3,3,4)$

물은 하루에 한 2 리터 정도는 일부러 먹으려고 하고 있어 요. 하루에 두, 세 잔 정도 에스프레소는 먹는 편입니다. 에 스프레소 마시고 나서는 기본적으로 한 $500 \mathrm{ml}$ 정도의 물 을 섭취하려고 노력합니다. 저녁은 조금 약간 이른 시간에 먹고, 자기 전 한 4 시간 전쯤 에는 웬만하면 음식을 섭취 안 하려고 노력합니다.....(중략)... 밀가루나 맵고 짜고 한 음식 을 먹지 않는 편입니다. 고기를 많이 먹는 것 같아요. 소고 기요. 그냥로스로 구워서 많이 먹는 편입니다. $(\mathrm{S} 4,3,4,6)$ 저녁에 음식을 피하고요. (중략)... 자극적인 음식을 먹었을 때 위산 역류가 되었을 경우 오랫동안 목에서 부종이 있어서 기침, 간지러움 동반하는 그런 증상이 있습니다. 쉴 때는 와 인 정도 마십니다. 커피를 자주 안 먹을 수 없어서 마시는데 물은 약 $3 \mathrm{~L}$ 정도 굉장히 많이 마시는 편이에요. (S5, 2-4)

특별한 관리법은 없고요. 그냥 꾸준히 하루에 한번 정도 도라지차나 생강차를 꼭 섭취하고 있고요. 그리고 감기 안 걸리기 위해서 비타민 $\mathrm{C}$ 를 꾸준히 하루에 두 알 씩 섭취를 하고 있습니다. 고기도 많이 먹고, 아메리카노를 많이 먹죠. 하루에 두세 잔은 꼭 마시는 것 같아요. 물은 하루에 꼭 2 리 터 이상은 꼭 마셔요. 꼭자기 전에 마시고 잡니다. 역류성 식 도염을 조심하는 편이죠. 그래서 밤늦게는 안 먹으려고 노 력하고 있습니다. (S6, 2-4)

이제는 거하게 먹으면 속도 더부룩하고 appoggia가 잘 안되고 호흡이 힘들고 해서 덜 먹으려고 노력을 하는 것 같 은데... (중략)... 물은 많이 먹는 편입니다. 요새는 차를 많이 마시거든요, 보이차라고... 뜨겁게... 한 1.5 리터 정도... 시원 한 물을 마시고. 커피는 뭐 하루에 한 잔 정도? 한 잔에서 두
잔? 마십니다. $(\mathrm{S} 7,11,12,18,19)$

물은 하루에 $2 \mathrm{~L}$ 이상을 마시려고 합니다. 유제품을 잘 안 먹는 편이거든요. 목에 가래도 많이 생기고. 그래서 유제 품은 좀 피하는 편입니다. 보신탕을 안 먹었는데, 목이 안 좋아서 먹었는데 너무 좋더라고요. 그래서 사실은 주기적 으로 먹는 편입니다. 음식은 좀 늦게까지 섭취를 합니다. 일 하는 시간이 늦게 마치고 하니까. 보통 열한 시? 열 시? 이때 까지 먹는 것 같습니다... (중략)... 술은 뭐 일주일에 한, 두 번 정도? 커피는 하루에 한 잔 정도는 먹는 것 같습니다. 고 기 같은 걸 먹으면 조금 좋은 느낌이 들어서 자주 먹는 편입 니다. (S8, 3, 6-9)

물은 보통 한 2리터 정도 마신다고 하는데 저는 조금 못 미치는 것 같습니다. 커피는 하루에 한 잔 이상 하고요. 물 을 많이 먹으려고 노력합니다...(중략)... 웬만하면 자기 전에 자기 전에 소화를 다 시키고 자려고 노력합니다. (S9, 3, 4, 6)

물은 수시로 많이 마시는 편이고요. 물을 한 2 리터 정도 마시는 거 같아요. 항상 성대의 촉촉함을 유지하기 위해서 수시로 물을 조금씩 마시고 있습니다. 커피도 하루에 한, 두 잔 정도는 마시는 편이구요. 알코올 종류는 성대를 많이 이 렇게 붓게 하므로 조금 자제를 하려고 합니다. $(\mathrm{S} 10,2,3)$

\section{운동 및 기타 습관}

면담자들은 평상시 음성 관리를 위해 조깅이나 런닝, 스트레칭 등 꾸준한 유산소 운동을 하였다. 하지만, 무거운 물건 들기와 같은 성대에 무리를 주는 웨이트 운동은 성대가 좋아지지 않았다는 경 험도 보고하였다. 또한, 목을 건조하지 않도록 실내 수분을 유지하 는 것을 중요시 하였다. 무엇보다도 예방적 차원을 중시하여 일부 성악가들은 가글링이나 감기가 걸리지 않도록 주의하고 있었다.

걷기나 빠르게 걷거나 약간 천천히 뛰는 걸 많이 하고 있 습니다. 30 분 정도에서 20 분 정도 하고 있습니다. 일주일에 3일 정도는 운동합니다...(중략)... 가습기를 사용하고 있습 니다. $(\mathrm{S} 1,2,3)$

웨이트 트레이닝을 주로 했는데, 하루에 한 시간에서 한 시간 반 정도를 주 한 5, 6회 정도 했습니다. (S3,2)

일주일에 거의 한 5 일에서 6 일 정도는 운동합니다. 제가 지금 보통 하는 운동은 오전에는 조깅을 많이 하고요. 조깅 은 한 기본적으로 한 30 분? 그리고 스트레칭 한 20 분 정도 하고요. (S4,4)

저는 목 관리를 위해서 깨끗하게 양치하고 목을 깨끗하 
게 가글한 후에 마스크를 쓰고 잠을 잡니다. 그랬을 때 훨 씬 더 아침에 목이 건조하지 않고요. (S5, 4-6)

성악가로서 감기가 걸리면 최악의 상황이 오기 때문에. (중략)... 그 전에 미리 미리 이비인후과에서 일 년에 두 번씩 목 상태를 확인도 하고요. (S6, 3)

가글하면서 한 시간 반에서 두 시간 정도 운동을 같이하 게 됐거든요. 스쿼트. 저는 가글을 매일 하거든요. 가글 하

면서 appoggia에 도움이 됩니다. (S7, 8-10)

운동은 지금 헬스를 하고 있지만 유산소 운동 쪽으로 하 고 있고요. 유산소 운동이 아닌 근력 운동을 했을 경우에 는 성대가 안 좋아진다고 느끼고 있습니다. $(\mathrm{S} 10,3)$

\section{공연 전· 중 · 후 음성 관리 및 습관}

\section{음성 관리 및 습관}

공연 시 최상의 목소리를 내기 위하여, 면담자들은 공연 전날 충 분한 수분 섭취, 수면, 음성 휴식을 통해 음성을 관리하였다. 공연 당일 아침에는 가급적 일찍 기상하여 목이나 몸의 긴장을 풀려고 노력하고, 공연 중에도 수분 섭취, 음성 휴식 또는 발성 워밍업을 하는 것으로 나타났다. $90 \%$ 의 면담자들은 공연 후에도 음성 관리 를 하는 것으로 나타났지만, 공연이 끝난 안도감과 함께 뒤풀이를 참여하는 경우도 종종 있었다.

공연 전날에는 자극적으로 연습하지는 않고, 간단한 연 습만 하고, 일찍 잠들고, 뒷날에 한 2 시간, 3 시간 전에 목을 풀면서 준비하는 스타일입니다. 공연 당일 아침은 충분히 잘 수 있을 만큼 자고, 만약에 깨어나면 좀 휴식을 취하면 서 (공연 시간을) 기다리는 편입니다. 공연하는 동안에는 목이 건조하지 않게 물을 입안에 머금고 있을 때가 많고요. 되도록이면 말을 하지 않습니다. 소리 발성만 조금 내고... 비염이 있기 때문에 목에 가래가 많이 껴서 허밍을 많이 하 는 편입니다. 공연 후에는 오로지 쉽니다. 그냥 말 안하고 쉽 니다. (S1, 4-6)

공연 전날은 무리해서 목을 쓰지 않으려고 하는 정도 입 니다. 공연 중에는 대화를 줄이고...공연 후에는 말을 절제 하는 편입니다. $(\mathrm{S} 2,4,5)$

공연 전날은 일찍 잡니다. 오전 공연이 있을 때 당일은 노 래하기 4,5 시간 이전에 일어납니다. 공연 당일에 20 분에서 30 분 목을 푸는 것 같습니다. 공연 중에는 말을 아끼는 걸 로 관리를 하고 있습니다. 공연 후에도 최대한 말을 안 하려 고 노력하는데 뒤풀이 같은 게 많이 잡히기 때문에 실질상
으로는 관리를 못하는 주의입니다. (S3, 2-4)

공연 전날은 목에 무리가 가지 않는 정도로만(음성을 사 용)하고 있습니다. 가능하면 더 빨리 자려고 노력을 하고. (공연 중에는) 딱히 음성 관리를 하진 않고요. 편하게 사람 들하고 대화를 나누는 편입니다. 왜냐하면 너무 말을 안 하 거나 그러면 이게 약간 가라앉을 수 있어서 저는 그렇게 하 는 편입니다. 공연 전후에는 조금 많이 쉬어 주려고 하는 편 입니다. $(\mathrm{S} 4,5-7)$

연주를 하는 날 같은 경우에는 발성을 20 분에서 천천히 30 분하고요. 그 이상은 넘기지 않습니다. 자고 일어나서 3 시 간 이후 됐을 때부터 목을 푼다는 생각을 갖고 있고요. 입술 트릴이나 호흡 운동부터 먼저 시작하고요. 소리를 과도하게 많이 내는 발성은 저는 원래 잘 하지 않습니다. $(S 5,4,5)$

저는 노래 부르기 3 시간 전에는 무조건 일어납니다. 일어 나서 움직여서 몸을 풀고, 목도 풀고, 발성도 무조건 합니 다. 공연 전날은 일찍 잡니다. (중략)... 공연 중에는 목이 가 라앉지 않도록 살짝 살짝 발성 워밍업을 하고 있습니다. 발 성 워밍업으로 오페라의 감정 기운을 계속 같이 갖고 가는 거죠. $(\mathrm{S} 6,6,7,9)$

공연 날 저는 발성 워밍업을 안 해요. 발성 워밍업은 공연 그 전날 하는 거죠. 가글 때 하는 거죠. 발성 워밍업은 잘 안 합니다. 공연 후에는 ... (중략)... (귀가해서 가글하고 쉽니 다.) $(\mathrm{S} 7,6,16)$

공연 전날은 일찍 잡니다. 보통은 평균 한 여섯 시간 정도 자는데 큰 공연이 있는 날에는 한 최대한 열 시간 정도 자 려고 노력합니다. 공연 시간 네 시간 전에 항상 기상을 합니 다. 눈 뜨고 씻고 하면 30 분? 1 시간 있다가 목 풀기 시작하고 공연 준비하죠. 주로 허밍으로 목을 풉니다. 공연 중에는 앉아서 쉬죠. 소리는 안 냅니다. 공연 끝나고는 딱히 그런 건 없는 것 같습니다. 만일 damage가 많이 왔다 싶으면 그냥 한 며칠 쉬는 거? ( $(\mathrm{S} 8,4-7)$

무대 뒤나 올라가기 전에 워밍업을 하고 올라가죠. 목과 몸이 처지지 않게 계속 움직여보고 계속 움직여봅니다. 공 연 후에는 매일 공연이라서... 오늘 공연 마치고 또 내일 다 른 공연이 있고 이러기 때문에... (중략) (S9, 7, 8)

공연 전날은 연습의 양을 조금 적게 하는 편입니다. 공연 4시간 전에 일어나는 편입니다. 우선 몸이 좀 깨고 나서 발 성 워밍업과 노래를 다해서 30 분 정도 하는 거 같습니다. 공 연 중에는 쉬려고 합니다. 공연 후에는 충분한 수면을 좀 취 하려고 합니다. $(\mathrm{S} 10,5,6)$ 


\section{식이 관리 및 습관}

면담자들은 경험상 알코올이나 카페인 음료가 목소리에 나쁜 영 향을 주며, 공연 전이나 공연 중 뿐 아니라 공연 후에도 목소리 회복 에 나쁜 영향을 준다는 것을 인지하고 있었다. 따라서, 면담자들은 공연 전.중·후에 카페인이나 알코올 섭취를 가급적 줄이고, 공연 전 에는 목에 영향을 줄 수 있는 유제품이나 카페인 대신 따뜻한 차나 물을 마셔서 수분 섭취를 하는 것으로 나타났다. 또한, 열량 보충을 위해 고기를 섭취하기도 하지만, 반대로 위산 역류를 걱정하여 오 히려 육류를 섭취 하지 않거나 과식을 삼가한다는 의견도 있었다.

공연 전날은 자극적은 음식은 많이 먹지는 않습니다. 특 히, 저는 고기류는 많이 먹지는 않고요. $(\mathrm{S} 1,4)$

공연 전날은 유제품이나 카페인을 줄이는 편이고... (중 략)... 취침 전 3 시간 동안 음식을 섭취하지 않도록 최대한 그러려고 노력하고 있습니다. 공연 중에는 카페인 섭취를 줄이고 모과차나 미지근한 물로 건조하지 않게 만들어주 는 정도... (중략)... 공연 후에는 과식과 과음을 절제하는 편 입니다. $(\mathrm{S} 2,4,5)$

공연 전날에 저는 단백질 위주의 고기, 육고기를 많이 섭 취하고, 공연 중에는 최대한 수분 섭취하고, 공연 후에는 술은 잘 안 마시려고 노력합니다. $(\mathrm{S} 3,3,4)$

공연 전에 술을 마시거나, 커피를 많이 마시거나 그러진 않고요. 그리고 물을 더 많이 마시려고 노력하고, 그리고 가 능하면 저녁을 잘 안 먹고요. 조금 간단하게 과일이나 이런 종류로 먹거나, 몸이 좀 안 좋거나 기운이 딸린다는 느낌이 들었을 때는 고기 섭취를 좀 하는 편입니다. 공연 중에는 물 을 더 많이 마시는 편이고요. 커피는 피하는 편이고요. (S4, 5-7)

공연 전날 같은 연주 전이나 중요한 음성을 써야 될 경우 에는 위산 역류 같은 걸 되게 조심하구요. 연주가 다 끝난 후에는 사실은 음식을 편안하게 먹죠. 술을 먹으면 그 다음 날 며칠 동안 목이 안 좋아요. 연주 하고 나서는 술을 먹거 나 과도한 음식을 먹는 것이 굉장히 안 좋습니다. 어쩔 수 없이 먹은 날은 한 3 일 정도는 굉장히 잘 목을 쉬어 줘야 되 더라고요. $(\mathrm{S} 5,2,6)$

공연 전에 항상 무조건 물이나 비타민, 혹시나 감기에 최 악의 컨디션이 안 되게 비타민 C 섭취를 하고 물을 한 1리터 정도 자기 전에 실컷 먹고 잡니다. 고기는 괜히 역류성 식도 염에 걸릴 수도 있고 더 안 좋은 것 같아요. 그냥 물 많이 마 시고 평소처럼 행동하는 게 제일 좋은 컨디션인 것 같아요.
공연 당일은 연주하기 전에 열량, 당이 많이 필요하니까 연 주할 때만 초콜릿도 조금 섭취하는 편인데요. 공연 후에는 집에 가서 혼자서 맥주 시원하게 딱 먹고, 물 마시고 잡니다.

$(\mathrm{S} 6,3,6,10)$

오전 공연 날은 3 시간이나 3 시간 반 전에 일어나서 무조 건 아침을 챙겨 먹으려고 하죠. 공연 중에는 저는 일부러 물은 많이 마십니다. $(\mathrm{S} 7,11,14,15)$

공연 전날은 보통 고기를 구워 먹죠. 공연 중에는 계속 물 마시고. (중략) $(S 8,4,5)$

공연 전날 고기류를 적당히 조금은 먹으려고 합니다. 공 연 당일에는 소화가 잘 되는 위주로 합니다. 공연 팀에서 보 통 도시락을 많이 주니까 식사를 많은 양은 안 먹고 적절히 조금만 먹고 있습니다. 공연 중에는 물을 좀 많이 마시는 편 이구요. 공연 후에는 몸이 피곤한 상태에서 과식과 과음을 하면 피로감이 공연을 끝나고도 회복하는 시간이 많이 걸 리기 때문에 요즘 많이 자제하고 절제를 하려고 하고 있습 니다. (S10, 4-6)

\section{목이 아플 때 음성 관리 및 습관}

\section{목이 아플 때 음성 관리}

전문 오페라 성악가는 오페라 공연을 위하여 평균적으로 무대에 서 약 2 시간 가량 노래와 연기를 한다. 긴 시간의 연속적인 오페라 리허설과 2 일에서 3 일동안 계속되는 공연, 그리고 오케스트라를 뛰어 넘는 강력한 소리를 산출해야 한다는 부담감은 음성 피로를 유발하기 쉬우며, 자신의 의지와 상관없이 성대를 남용하게 되는 경우가 많다. 본 연구의 면담자들도 목이 아플 때 불필요한 말을 자 제하고, 음성 휴식을 하거나 나쁜 공기를 피하고 목을 청결하게 하 는 등 음성 위생에 신경을 쓰는 것으로 나타났다.

목이 아플 때 말을 하지 않고..... (중략)... 입안에 너무 자 극되지 않는 가글 같은 것도 하고요(S1, 6, 8)

말을 하지 않고 휴식을 취합니다. (S2, 6)

목이 아플 때 말도 안하고 노래도 안 듣고 온도와 습도 그 런 걸 조절한다음에 목을 감싼채로 잠을 많이잡니다. $(\mathrm{S} 3,4)$ 목이 아플 때는 가장 좋은 건 그냥 아무 소리도 안 내고 노래하지도 않고 쉬는 게 가장 좋아요. $(\mathrm{S} 5,6)$

목이아플 때 말을 안 하고, 그리고 집에서 잡니다. $(\mathrm{S} 6,12)$ 말을 안 하죠 일단은. 안 좋은 공기를 피하려고 합니다. $(\mathrm{S} 9,9)$ 


\section{목이 아플 때 식이 및 약물 섭취}

면담자들은 목이 아플 때 수분 섭취에 중점을 두었다. 특히, 미지 근하거나 따뜻한 물 또는 차를 주로 마시거나 꿀물, 도라지와 같은 식품을 섭취하는 경우도 있었으며, 공연 후 성대 부종을 가라앉히 기 위해 얼음을 입에 물고 있는 경우도 있었다.

목이아플 때 미지근한 물이나차를자주 마시는 편입니다.

$(\mathrm{S} 1,6)$

도라지 섭취합니다. 도라지 가루. $(\mathrm{S} 3,4)$

따뜻한 꿀차라던가 따뜻한 물을 좀많이마시는 편이에요.

$(\mathrm{S} 4,7)$

목이 아플 때 물을 많이 마시고. $(\mathrm{S} 6,12)$

물을 또 많이 마셔요. 최대 수분을 좀 많이 이렇게 보충

을 해주고. (S9, 9)

저는 미지근한 물을 이용을 하지만, 노래를 하고 성대가 많이 부어 있을 때는 얼음을 목에 많이 넣고 있습니다. 목 구멍 근처에 얼음을 머금고 있으면 붓기가 가라앉는다는 느낌을 많이 받아서... $(\mathrm{S} 10,10)$

면담자들의 약물 처방은 주로 스테로이드에 관한 것이었는데, 공 연 시 인후두 통증이나 음성 문제로 인한 처방을 받은 경험이 있다 고 하였다. 스테로이드는 목이 아프거나 소리가 나오지 않을 때 당 장에는 일시적인 효과가 있지만, 공연 때 목을 혹사하게 되고 회복 시간이 길어지는 부작용도 있다는 의견을 제시하였다.

스테로이드 처방 경험은 많습니다. (공연 전) 빠른 시간 내에 (음성의) 회복력이 좋았습니다. 순간적으로 소리를 내 야 될 급박한 상황에는 효과가 좋았습니다. $(\mathrm{S} 1,17,18)$

스테로이드 처방 경험은 잘 기억이 나지 않습니다. (S2, 6-8) 저는 스테로이드 복용에 대해서는 그다지 긍정적인 반응 의 사람은 아닌데요. 제가 약을 먹어본 적이 없어서 어떤지 잘 모르겠지만 주변에서 애기를 들었을 때 스테로이드제가 오늘 공연이 있다고 생각했을 때는 일시적인 효과는 있다 고 생각하지만, 그게 계속적으로 복용한다면 그렇게 좋은 효과를 준다고 생각하진 않고요. 기본적으로는 그냥 목 관 리를 제일 잘 하는 게 좋을 거라고 생각합니다. 약에 의존도 가 높아질 수 있기 때문에 스테로이드제 복용한다는 것에 긍정적으로 생각하는 편은 아닙니다. $(\mathrm{S} 4,15,16,21)$

목 상태가 굉장히 많이 부었을 때 한번 스테로이드를 맞 아본 적이 있는데. 저는 굉장히 안 좋았어요. 그래서 저는
스테로이드 사용을 안 좋게 생각을 하고 안 했으면 좋겠어 요. 성악가들이. 그렇게 해서 연주를 하면 목을 굉장히 혹 독하게 학대하는 게 돼 버려요. 그리고 그렇게 하다 보면 호 흡에 근육을 잘 써서 노래 하기 보다 힘으로 노래를 하는 거죠. (S5, 8, 9)

스테로이드를 처방 받은 경험은 귀국하고 두 번 정도 있 어요. 썩 좋은 것 같지는 않습니다. 맞을 때 당시에는 괜찮 은데 그렇게 공연이 끝나고 나면 damage가 좀 오래 오래 가 더라고요. 보통은 오페라 끝나고 나면 무리하고 또 술도 먹 고 이래도 목이 가도 하루 이틀이면 돌아오는데, 스테로이 드 맞고 무리를 하니까 한 일주일 넘게 걸리는 것 같더라고 요. 그래서 정말 급한 경우 아니면 안 하려고 노력을 합니다.

$(\mathrm{S} 8,11,12)$

스테로이드는 공연이 오늘이고 내일인데 목이 쉬어서 안 돌아올 때 그 때는 급성으로 제가 조금 해 달라 그러죠. 지 푸라기라도 잡고 싶은 마음에... 저는 의사 선생님께 일단은 쌘 걸로 놔주시고.. (중략)... 공연 있으니까 공연하게끔 성대 조금 작동하게끔 그렇게 만들어주세요 하고 어필을 하죠. $(\mathrm{S} 9,11,12,14)$.

스테로이드는 두 번 받은 거 같습니다. 장단점이 있는데, 장점은 꼭 노래를 해야 되는데 성대 상태나 목의 상태가 좋 지 않을 경우에 노래를 해야 되면 주사를 맞아야 된다고 생 각합니다. 그래서 어느 정도의 시간은 스테로이드의 성분 을 이용해서 노래가 나오는 것 같아요. 단점은 안 좋은 목소 리를 주사를 이용을 해서 소리를 내야 되니까 일시적으로 는 잘 될 수 있더라도 약 기운이 떨어 졌을 경우에는 오히려 상처 난 부위를 더 상처 나게 이렇게 만들어서 성대 회복 기 간까지 많은 시간이 걸리는 거 같았습니다. $(\mathrm{S} 10,4,8,10)$

\section{음성장애에 대한 의학적 치료 및 음성 치료에 대한 인식}

목소리가 나지 않거나 목이 심하게 아플 때 바로 병원을 방문해 서 후두내시경 검사나 약물이나 의학적 처치를 받았으며, 정기적으 로 성대 검사를 받기 위해 병원을 방문하는 경우도 있었다. 하지만, 빈번히 일어나는 목이 아픈 경우는 증상의 정도에 따라 참았다가 병원을 방문하기도 하였다.

소리가 나지 않을 때 이비인후과 가서 성대를 내시경으 로 본 경험이 두세 번 있습니다. ...(중략)... 일 년에 한두 번 감기 기운이나 무리가 될 때 보러 가고 있습니다... (목이 아 플 때) 일단 병원에 가서 처방을 받고, 심할 때는 뭐 소리가 
당장 안 나오겠다 싶으면 병원을 바로 가고 어느 정도 그냥 견딜 만 하면 조금 참았다가 가고 있습니다. (저는 음성 문 제로 약물 처치를) 일 년에 한, 두 번은 받았습니다. (중략)... (저는 만성적) 비염 치료를 위해 원적외선 같은 불빛이 나오 면서 (집에서 스스로) 코 치료하는 기계를 샀습니다. (S1, 2,

\section{$3,6,7,10)$}

목이 많이 아플 경우에는 병원에 가지요. 그런데 이제 빈 번히 항상 일어나는 목 아픈 그 패턴은 보통 아니까많이 아 프지 않으면 그냥 집에서 관리하는 편입니다. 2,3 년 정도 질 환이 왔을 때 그 쯤을 기점으로 이비인후과에 매우 자주 갔었는데 그 이후에는 자주 가지 않습니다. $(\mathrm{S} 2,6)$

목이 아플 때 저는 바로 병원에 갔습니다. 이비인후과로 갑니다. 그냥 좀 간단한 감기 같은 거라면 약을 처방 받아서 오죠. 주사를 맞거나. 제 성대는 6,7 년 전에 본 것 같습니다. 저는 전혀 문제가 없어서 이비인후과를 방문해서 성대를 안 봤습니다. $(\mathrm{S} 3,4,5,7)$

아플 때 병원을 꼭 가죠. 조금만 이상하면 바로 병원을 가는 스타일입니다. 좀 예민해져 가지고 목이 안 좋으면. 성 대검사 하고, 보통 이제 약 받아오고, 또 힘들 땐 주사 맞고. 성대 검사를 1 년에 한 번씩은 주기적으로 합니다. 갑자기 소 리에 이상한 변화가 있거나 하면 바로 찍어보고... (S8, 7, 8)

병원도 정기적으로 6개월에 한번 씩 성대 검사를 하긴 하는데요. 목에 이상이 왔을 때는 병원을 갑니다. 2,3 일 정 도 제가 숙면을 취하고 물을 많이 마셔도 안 되면 병원을 가 죠. (S6, 12, 13)

일부 성악가들은 가능한 병원 방문을 피하고 목이 아플 때 집에 서 가장 먼저 스스로 증상을 완화하기 위한 방법을 찾는 경향이 있 는 것으로 나타났다. 면담자 중 일부는 병원 대신 경험을 통한 오랜 노하우가 있다고 생각하는 성악 교사를 찾거나 방문하여 방법을 구하기도 하였다.

가능하면 병원은 조금 피하는 편이고요. 뭔가 약간 발성 에 문제가 있어서 그렇다고 생각을 해서 선생님을 찾아가 는 편이였습니다. 감기 기운이 있어서 몸이 좀 안 좋을 때는 기침을 하거나 이런 정도가 아니라면 일단은 레슨 선생님 께 가서 노래는 하지 않더라도 발성을 조금 해서 성대 운동 을 해주는 게 좋다고 생각을 하고요. 그런데 만약에 기침을 하는 경우나 이럴 때는 기침을 하면서 울림이 생기거나 마 찰로 인해 별로 좋지 않다고 생각하기 때문에 기침을 하는
경우에는 그냥 쉬는 게 낫다고 생각합니다. $(\mathrm{S} 4,7,8,22)$

어느 정도 예상하는 거랑 뭐 비슷하긴 하지만 어쨌든 목 을 한번 확인하고 그거에 맞게끔 대처하기 위해 확인 차 병 원에 갑니다. 노래를 계속 안 할 경우는 약을 먹어도 되는데 노래를 계속 할 때 약을 먹으면서 연주를 하는 것은 굉장히 안 좋아서 그것도 막 과도하게 사용하지는 안습니다. 병원 에 가서 막 자주 가서 약을 먹거나 그러지는 않습니다. 그 때에 따라 다른데요. 쉴 수 있는 시간이 있고 자체적으로 쉬 면 될 것 같다고 판단했을 때는 쉬고, 느낌이 좀 이상하다 고 느꼈을 때 그 다음에 좀 얼마나 심각한가 싶을 때는 병원 에 가서 한번 확인을 합니다. $(\mathrm{S} 5,7,10,11)$

아플 때 증상이 되게 좀 심한 거 같으면 병원에 가보죠. 저는 성악 인생이 23,24 년 됐는데 목 감기 때문에 한번 봐 주세요 하고 병원에 가고.. (중략)... 목이 노래를 너무 많이 해가지고 목이 아파서 성대를 검사 해본 적은 없어요... (S7, 20,21)

목 안 좋을 때는 물론 스트레스를 많이 받죠. 그런데 저 는 목이 잘 자주 아픈 경우가 잘 없어요. 저는 솔직히 그 고 음 가수가 아니라서 목에 직접적인 damage가 그리 무리할 정도로 찾아오고 이럴 경우가 잘 없습니다. 예전에는 병원 다녔죠. 그런데 어.. 수차례 경험을 해보고 같은 비슷한 그 런 병증이 찾아오면 제 나름대로 이제 노하우가 있어서 다 똑같더라고요. 그냥 물 먹고, 잘 자고, 잘 쉬고, 말 안 하는 게 그게 답인 거 같아서 병원 신세는 안 지고 그냥 혼자 조 용히 그렇게 합니다. $(\mathrm{S} 9,9,10)$

이비인후과는 거의 안가는 편입니다. 일 년에 감기가 온 다든지 그럴 경우엔 가되, 목이 안 좋아서 가는 경우는 거 의 없는 것 같습니다. (가장 최근에 성대를 본 적은) 1 년 정 도 전에 본 거 같습니다. $(\mathrm{S} 10,7)$

한편, 음성 치료에 대해 알지 못하거나, 음성 치료를 받은 경험이 거의 없는 것으로 나타났다. 하지만, 음성 치료가 발성의 모든 것을 다 해결해 줄 수는 없더라도 음성에 문제가 생겼을 때 성대에 불필 요한 손상을 주지 않도록 올바른 소리를 낼 수 있는 방법을 알려 주 거나 성대에 나쁜 영향을 주는 발성 패턴 및 습관에 대해 조언해 줄 수 있을 것 같다는 긍정적인 의견도 있었다.

음성 치료.. 뭐 어떤 거 하는 거죠? $(\mathrm{S} 7,31)$

제 생각에 음성 치료는 소리 내는 방향을 잘 못 잡았을 때 생기는 damage를 치료하는 것? 음성 치료사는 말을 못 
하는 사람을 치료하는 것 같습니다. 소리를 못 내고... 저는 음성 치료사의 경험이 없습니다. 제가 음성 치료사를 방문 하지 않는 이유는 지역적인 한계였습니다. 제가 거주하는 지역에는 이비인후과도 하나밖에 없습니다. 저는 음성 치 료사가 잘못된 성대의 움직임이나 이런 발성적인 걸 잡아 줄 수 있을 거라, 도움이 될 거라 믿습니다. 받아본 적은 없 지만 받고 싶은 생각은 있습니다. 제가 음성 치료를 받는다 면 소리를 올바르게 냈을 때 성대의 정확한 움직임을 할 수 있게끔 성대를 쓰는 방법을 알고 싶습니다. 어떻게 호흡을 했을 때 성대가 불필요한 damage가 없을 수 있는지 알고 싶습니다. 저는 음성 치료를 긍정적으로 생각하는 편입니 다. (S1, 10-12)

저는 음성 문제로 수술이나 약물 처치를 받은 경험이 없 습니다. 음성 치료는 소리 내는 방법을 정확하게 알려줌으 로써 음성을 치료하는 방법? 제가음성 치료를 받는다면 평 소 말 습관에 있어서 조언을 받고 싶습니다. 저는 음성 치료 와음성 치료사를 신뢰합니다. (S2, 12, 13)

저는 음성 치료가 일반 사람들도 말을 해도 입안에서 소 리가 잘 안 빠져나오는 그런 사람들이 꽤 있잖아요? 그런 사 람들을 일상 생활을 할 수 있도록 도와주는 게 음성 치료 인 것 같고... 제가 음성 치료를 받는다면... 글쎄요... 문제 가... 저는 없어서... 생각해 본 적이 없었습니다. 저는 음성 치료사가 전문적으로 목을 쓰는 아나운서, 성악가들에게 목에 문제가 생겼을 때 도움을 줄수 있는... 도움을 줄수 있 다고 생각합니다. 저는 음성 치료와음성 치료사를 네. 신뢰 합니다. 왜냐하면 과학적으로 그런 쪽으로 연구도 더 하신 분들이고, 인체 쪽으로 더 많이 아시니까. 그렇다고 생각합 니다. $(\mathrm{S} 3,10,11)$

음성 치료를 잘은 모르겠지만, 성대에 무리가 가거나, 성 대결절이나 그런 걸로 인해서 문제가 생겼을 때 받는 치료 라고 저는 생각합니다. 제가 음성 치료를 받는다면 제가 하 고 있는 발성이나 아니면 제가 말하는 제 톤? 이게 과연 제 가 잘하고 있는지? 그리고 그게 제 성대에 문제가 되지는 않 는지? 그런 거에 대해서 알고 싶습니다. 저는 음성 치료사는 말하는 습관이나 성악가 같은 경우에는 노래하는 거에 대 해서, 그리고 제 성대가 어떻게 잘 쓰이고 있는지, 어떻게 했 을 때 무리가 가는지? 그런 전반적인 것들에 대해서 설명해 주시고, 그리고 만약에 나쁜 부분이 있다면 그거를 고쳐 주 시지 않는 분인가 생각합니다. ..(중략)... 저는 음성 치료로 모든 게 다 해결이 된다고 생각하진 않지만, 저희가 아프면
병원에 가서 치료를 받는 것처럼 안 좋은 부분에 대해서는 음성 치료 선생님께서 도움을 주실 수 있다고 생각합니다. $(\mathrm{S} 4,8,12,13,15)$

음성적으로 잘못 사용해서 아프거나 아니면 제대로 소 리를 못 내고 있는 사람들이 있어서 저는 음성 치료, 소리 를 내는 방법, 건강하게 내는 방법들이 굉장히 필요하다고 생각합니다. 제가 음성 치료를 받는다면 간혹 노래할 때 성 대가 벌어지는 경우가 있는데, 물론 훈련을 통해서 극복을 하지만, 더 건강하게 노래할 수 있는 방법이 있다면 더 좋겠 죠? 음성 치료를 통해서? 저는 음성 치료를 신뢰합니다. 네. 그렇게 생각하고 있습니다. 저는 음성 치료사가 발성 문제 의 해결까지는 아니지만 도움은 줄 수 있다고 생각합니다.

$(\mathrm{S} 5,14,15)$

음성 치료를 받아 본 성악가 중에는 음성 문제가 생겼을 때 후두 마사지나 이완 등이 도움이 되었으나, 성악 발성이나 호흡을 이해하 고 치료해줄 수 있을 지에 대해서는 의문을 가졌다. 즉, 성악가들은 음성언어치료사들이 과학적이고 이론적인 지식이나 상담에 그치 지 않고, 성악가의 발성이나 호흡법에 대해 이해하고, 실제적으로 적용하고 사용하는 것을 보여줄 수 있을 때 신뢰감을 줄수 있을 것 이라고 강조하였다.

음성 치료는 독일에 있을 때 (폴립이 생겨서) 아는 분이 한번 추천을 해줘서 가르쳐 쥤는데요. 크게 도움은 안됐어 요. 그래서 연습으로, 내가 연습했던 대로, 무조건 연습해 서 (방법을) 찾았어요. 아니면 무조건 쉰다고 해서는 절대 로 낫지를 않더라고요. 아마 제 생각은 평생 한 열 명 성악 가 중에, 여섯 명 일곱 명 정도는 자기의 목이 좋은 사람은 잘 없는 것 같아요. 온전한 목을 갖고 있는 사람은 잘 없고 요.. 자기가 연습을 함으로써 그거를 안 건드리게끔. 안 좋 은 부위를 안 건드리게끔. $(\mathrm{S} 6,13,14)$

저는 음성 치료를 독일에서 받아본 적 있습니다. 의료보 험이 돼서 $\cdots$. 제가 한 번 목이 좀상해 가지고 한 6 개월 정도 일주일에 2 회 받았습니다. 그때 성대 마사지 하는 거 하고, 성대 근육 주위 푸는 거 하고 그런 걸 좀 많이 도움을 받았 었습니다. 지금도 이완시켜주고 마사지해주고 이런 거 있으 면 좀 받아보고 싶은 의향은 있습니다. 저는 음성 치료가 도움은 된다고는 생각합니다. 하지만 $100 \%$ 신뢰는 아닌 거 같습니다. 사람의 신체 구조가 다 다른데 신체 구조에 대해 서 호흡의 양도 다른데 모든 발성에서 그걸 다 적용을 한다 
는 것은 저는 오류가 있다고 생각합니다. 성악가가 아닌데 성악가적인 발성과 호흡들을 모든 거를 이해를 하고 있다 할 수 있다면 이해를 하는 것과 하는 것은 분명히 다르잖아 요? 그래서 그걸 완벽하게 할 수 있는 사람이 한다면 조금 더 신뢰가 갈 수도 있을 것 같은데. 제가 봤던 치료사들은 그런 분들보다는 전문적으로 음성에 대해서 기본적인 이 론을 알고 계시는 분들이 많았기 때문에 $100 \%$ 신뢰한다는 건 좀 오류가 있는 것 같습니다. (S8, 22-25)

저는 음성 치료에 대해 잘은 모릅니다. 제가 음성 치료를 받는다면 제 몸을 또 한 번 또 상담하고 치료받고 그러고 싶 은 마음이 있죠. 제가 갖고 있는 성대를 제가 다 아는 건 아 니니까. 저는 음성 치료사에게 무조건적으로는 신뢰감이 들지는 않겠죠. 그런데 만나보고 상담해보고 하는 가운데 음성 치료사가 얼마나 목을 써 보셨나, 일명 현장 일은 잘 아시는가가 신뢰할 수 있는 고려 사항이 되겠죠. 현장은 모 르고 사무만 알고 이러면 안 되니까. $(S 9,28,29)$

저는 음성 치료를 받았던 경험이 한 번도 없는 것 같습니 다. 별로 음성 치료에 대한 거를 별로 받아야 되겠다는 느 껴보지 못해가지고요. 음성 치료를 받는다고 한다면? 정말 나는 테너와 바리톤으로 갈 수 없는지? 성대 상태가? 에 대 해서 면담하고 싶습니다. 전문적으로 노래를 하고 있기 때 문에... 어느 정도 많은 부분은 제가 제 성대 상태를 알 수 있을 것 같아요. 그런데 성대 상태가 안 좋다는 느낌을 받으 면 이비인후과에 가서 내시경을, 엑스레이를 좀 찍어 보는 편입니다. 음성 치료사가 발성 문제를 해결할 수 있다고 저 는 신뢰하지 않습니다. 목의 상태를 보고 의학적인 도움을 받고 약을 드시고 수술을 한다든지 그런 말은 할 수 있겠지 만 발성의 부분까지 해결을 해줄 수 있는 부분은 아니라고 봅니다. $(\mathrm{S} 10,15,16)$

\section{음성에 대한 지식}

\section{호흡과 발성 해부 및 생리에 대한 이해}

전문 성악 연주자들은 호흡 및 발성 훈련을 위해 해부학 및 생리 학적인 기초 지식을 갖추어야 할 필요가 있다. 호흡 및 발성에 대한 해부학적 지식의 이해 측면에서 보았을 때, 본 연구의 면담자들은 발성이나 호흡의 중요성을 매우 강조하지만, 호흡이나 발성 기관에 대해 잘 모르거나 잘못 이해하고 있는 경우도 있었다. 특히, 일부 성 악가들은 성대나 폐, 횡격막와 같은 의학적인 해부학적 용어에 익 숙하지 않았으며, 불확실하거나 이해도가 낮은 것으로 나타났다.
폐의 위치는 가슴 윗부분부터 명치 쪽까지요. 정상 성대 의 색깔은 살구 빛보다 조금 진한 느낌? (S1,7)

정상 성대는 하얀색이지요. 폐의 위치는 정확하게는 모 르는데 갈비뼈 안쪽에 있는 것으로 알고 있습니다. (S2,9)

정상 성대는 본 적이 없어요. (중략)... 폐의 위치는 잘 모 릅니다. 가슴? 명치? $(\mathrm{S} 3,7)$

정상 성대는 핑크색이라 하기엔 좀 그렇지만 약간 옅은 핑크톤을 띠지 않을까라고 생각합니다. 폐는 양쪽에 두 개 있지 않나요? 음... 정확하게 잘 모르겠지만 가슴 밑에서 복 부 위쪽? 배꼽 위쪽? 그 사이에 있지 않을까요? 저희가 알고 있는 뭐 횡격막 그쪽? 그쪽에 있지 않을까 생각합니다. (S4, $4,5)$

성대는 정상 색깔은 흰색이 가장 건강한 걸로 알고 있고 요.. 핑크색은 안 좋은 상태고 더 어두운 사람은 더 안 좋죠. 폐는 갈비뼈 안에 횡격막 위까지 있는 걸로 알고 있습니다. $(\mathrm{S} 5,5,6)$

성대는 하얀색이고요.. 폐는 가운데에서 양쪽에 있는 것 아닐까요? $(\mathrm{S} 6,20)$

성대는 선홍색이였나? 폐? 횡격막 바로 위에 있는 거 아 니에요? (S7, 24)

폐가 쇄골뼈 밑에서부터 갈비뼈 밑에서 두 번째인가? 세 번짼가? 거기까지? $(\mathrm{S} 8,16)$

정상 성대는 약간 선홍 빛? 하얀 색에 가까운 선홍 빛 이 었던가? 폐는 등 쪽에 있죠. 양 옆에 등에? 등에 양 옆으로 이렇게 퍼져 있죠. $(\mathrm{S} 9,11,12)$

건강한 성대는 살짝 분홍빛을 띄지 않을까요? 폐의 위치 는 오른쪽 아닌가요? $(\mathrm{S} 10,9)$

호흡과 발성의 생리적 기전에 대한 지식의 정도를 살펴 보았을 때, 대부분의 면담자들은 추상적으로 설명하거나 개인적 경험을 강조하였다. 가창 시 호흡의 패턴은 안정적이고 자신감 있는 소리 를 내기 위하여 흥복식 호흡을 사용하는 것으로 나타났다.

음성 산출은 폐나 근력이 움직이면서 공기가 채워지는 압으로 인해서 소리가 밖으로 나오면서 성대가 서로 마찰 을 일으키면서 비벼지면서 소리가 난다고 저는 이해하고 있 습니다...(중략)... 들숨 시 횡격막은 부풀어 오릅니다. 네. 상 승합니다. (복식호흡 시 배는) 나오고... 흥복식 호흡을 저는 같이 쓰고 있습니다. 들숨 시 후두의 변화는 잘 모르깄네 요.. 내려가는 게 맞는 것 같습니다. $(\mathrm{S} 1,15,16)$ 
음성은 성대가 비벼지면서 발생이 된다고 생각합니다. 들숨 시 횡격막이 내려가지요. 정확한 복식 호흡을 하게 되 면 가장 아랫배는 좀 당겨지면서 횡격막이 내려가고 아랫 배는 좀 당겨지면서 그 가운데는 나온다고 생각합니다. 고 음 파트(성악가)들은 가슴 호흡(흥식호흡)을 좀 사용해야 되는 것으로 알고 있습니다. 대신 복식호흡이 매우 잘 바탕 이 되고 난 후에 사용 해야지, 아니면 조금 위험한 것 같습 니다. 들숨 시 후두는 내려갑니다. (S2, 9-11)

소리는 성대가 붙어서 나온다고 생각을 하는데... 들숨 시 횡격막은 팽창이 되죠. 복식호흡을 하면 배가 나오겠죠. 흥복식 호흡 사용이 좋다고 생각합니다. 대부분 성악가들 은 복식호흡을 하라고 하지만, 웨이트 트레이닝을 해보니 까, 가슴이랑 복압이랑 같이 주니까 더 강한 파워가 나오더 라고요. 들숨 시 후두는 올라간다고 해야 하나요? $(\mathrm{S} 3,8,9)$

하지만, 흥복식 호흡을 바람직하지 않다고 여겨 복식호흡만 사 용하거나 성별에 따라 흥식호흡과 복식호흡사용의 차이가 있어야 한다고 주장하는 경우도 있었다. 복식호흡의 경우, 단전호흡과 같 은 의미로 사용하였으며, 대부분 아랫배를 당기면서 들어가고 윗배 가 나와야 한다고 하였으나, 반대로 아랫배가 더 나와야 한다는 의 견도 있었다. 들숨 시 횡격막의 위치는 대부분 하강하는 것으로 알 고 있었으나, 흡기근인 횡격막이 수축하여 내려간다기 보다는 아랫 배가 들어가면서 횡격막이 수동적으로 내려가거나 공기가 폐 안에 들어가서 횡격막이 팽창하는 것으로 이해하는 경우가 많았으며 반 대로 횡격막이 상승한다고 잘못 이해하는 경우도 있었다. 후두의 위치는 성별 혹은 성구(두성 및 가성)에 따라 다를 수 있다고 강조 하였다.

소리는 호흡을 하는데 있어서 공기를 실어서 그 다음에 입 안에서 울림으로 인해서 밖으로 나간다고 저는 생각합 니다. 호흡을 들여 마셨을 때는 횡격막이 내려가야 한다고 생각하고요. 복식호흡은 저는 단전호흡이라고 생각하는 데, 일단 배꼽 위로는 호흡이 많이 올라오지 않는다고 생각 하고요. 왜냐하면 배꼽 위로 호흡이 만약 많이 들어가게 되 면, 횡격막도 많이 내려가지 않고, 가슴 쪽으로 호흡이 많이 치솟아 오를 수 있어서. 일단은 저는 배꼽 아래의 약간 단전 쪽을 많이 사용해야 된다고 생각합니다. 윗배가 아예 안 나 오는 건 아니지만, 단전이 더 나와야 된다고 생각합니다. 흥 복식 호흡사용은 흥부의 호흡도 써야 하지만 흥부의 호흡 만 사용하는 것은 아니라고 생각합니다... (중략)... 들숨 시
후두는 저는 내려간다고 생각합니다. $(\$ 4,10,11)$

음성이 만들어지는 건 폐에 들어간 공기가 성대를 지나 면서 진동을 해서 소리가 만들어지는 걸로 알고 있고요. 복 식 호흡 시 배가 나옵니다. 사실 윗배가 더 많이 나온다고 봐요. 흥복식 호흡은 동시에 이루어지죠. 그렇지만 흥식만 가지고는 안된다고 생각하고요. 복식을 하면서 흉부가 올 라간 갈비뼈가 벌어지는 게 더 건강한 것으로 알고 있습니 다. 들숨 시 후두 위치를 내려 놓으려고 하는 것으로 알고 있습니다. 올라가지 않도록. (S5, 10-13)

숨을 마시면 횡격막이 저절로 팽창하게 되죠. 복식호흡 시 좀 빠른 곡은 횡격막 명치 쪽을 통해서 갈비뼈 제일 밑에 쪽을 숨을 놀라 듯이 팍 쉽니다. 느린 곡은 횡격막을 통해 서 숨을 천천히 부드럽게 쉬고... 흥복식 호흡은 아마 바리 톤이나 저음 가수들은 흥성을 많이 쓰는 것 같아요. 근데 저는 테너이다 보니까는 그냥 복식호흡을 많이 하고, 두성 을 많이 쓰는 것 같아요.(중략)... 정상적으로 들숨을 잘 쉬 었을 때는 후두의 위치가 자연스럽게 똑 떨어지게 되어 있 습니다. 호흡이 딸리거나 그러면 끌려 올라가죠. (S6, 20-22) 호흡이 코로 들어왔다 치면, 후두가 내려가고, 윗배가 나 오고 횡격막이 팽창돼서 버텨주는 것과 미는 힘과 후두가 내려간 힘이 딱 평형을 이룬 상태... (중략)... 복식호흡 시 저 는 아랫배는 들어가고 윗배는 나옵니다. (중략)... 저는 그냥 가슴은 안 나오는 거 같은데... 흥식호흡은 사용하지 않습 니다.. 들숨 시 후두의 위치는 내려가죠. 쇄골 정도? 쇄골까 지 내려갑니다. $(\mathrm{S} 7,24,25)$

소리는 호흡이 나가는 방향이 우리가 내는 소리라고 저는 항상 애기를 하거든요. 우리가 호흡을 가지고 호흡이 나가는 방향대로 우리가 성대에서 내는 진동을 울려서 앞으로 내준 다. 항상 그렇게 생각하고 있습니다...(중략)... 복식호흡시 배 가 나오죠. 저는 윗배가 나오고 위에 하고 뒤쪽하고 이렇게.. 저는 여학생들은 당연히 흥복식 호흡을 해야 된다고 생각 하고 가르치고 있습니다. 소프라노는 진가성을 같이 쓰기 때 문에 호흡을 어느 정도 예민하게 조절을 해야 될 필요가 있 다고 생각을 하거든요. 그래서 흥성을 같이 써야 된다고 생 각합니다. 들숨 시 후두가이제 내려가죠.( $(\mathrm{S} 8,16,17)$

소리는 폐의 공기가 성대를 지나면서 이 성대의 떨림이 이렇게 나와서 공기를 타고 상대방한테 그렇게 들려지는 게 아닐까라는 생각을 해봅니다. (들숨 시) 횡격막은 팽창 이 되죠. 발달해서 여기.. 옆으로도 튀어나오고 앞으로도 튀어나오고. 심지어는 뒤쪽으로도 튀어나오고. 흥복식 호 
흡은 바람직하지 않다고 생각합니다만...(중략)... 들숨 시 후두의 위치는 성악가들은 인위적으로 남자들 같은 경우 에는 내리죠. $(\mathrm{S} 9,16,17)$

소리는 호흡을 마시고요. 횡격막에 소리가 받쳐져 있고. 내려가 있고. 거기서 공기가 조금씩 나오면서 성대를 거치 고 비강, 마스크, maschera 쪽으로 소리가 나온다고 생각을 가지고 있습니다. 복식호흡을 하면요? 아무래도 횡격막을 많이 쓰면 그 부분이 조금 발달하는 걸로 알고 있습니다. 복식호흡 시 배가 나오죠. 아랫배도 아닌 윗배도 아닌 동시 에 두 개가 다 나오는 것 같아요. 명치 아래쪽으로. 흥복식 호흡은 그것을 추구를 하지 않고 있습니다. 들숨 시 후두가 내려가죠. 두성은 머리를 이용해가지고 후두를 내린 상태 에서 복식호흡에 바탕으로 해서 두성 머리 쪽을 이용한 거 고요...(중략)... 가성 때는 후두가 올라가죠. 그렇지 않을까 요? (P10, 9-11)

\section{성악 발성에 대한 이해}

본 연구에 참여한 면담자들은 오랫동안 성악 훈련을 받은 전문 오페라 성악가인 동시에 성악 교사로 일하고 있으나, 성악 발성에 대한 지식에 관해 조사하였을 때, $90 \%$ 가 두성과 가성의 발성법의 차이에 대해 잘 모르고 있었다. 특히, 성악가들은 가성을 사용해 본 적이 없거나 성악 발성에서 사용하지 말아야 한다고 주장하였으며, 가성을 성대가 약간 벌린 상태에서 발성하여 성대 접촉이 감소된 상태로 이해하고 있는 경우도 있었으나, 반대로 성대를 더 세게 부 딪혀 성대에 무리가 가는 발성으로 여기고 있었다.

두성과 가성의 차이는 정확히는 모르겠습니다. 두성은 head voice를 이용한 거고. 머리 쪽으로 소리를 울림을 더 주는 거고. 진성은 두성 머리를 거치지 않고 바로 목을 거쳐 서 소리를 뱉아내는 게 진성 아닐까요? 두성은 머리를 통해 서 나는 소리에요. 호흡을 쓰고 안 쓰고 차이 아닐까요? (S1, 16-18)

가성은 안 써야 한다고 저는 생각을 하거든요. 가성은 성 대 주변의 가짜 근육을 울려서 내는 거기 때문에 사용하지 않아야 한다고 생각을 하고... (중략)... 정확하게 성대가 비 벼져서 나는 두성 같은 소리를 내야 건강한 소리를 낼 수 있 다고 생각합니다. $(\mathrm{S} 2,11,12)$

두성과 가성의 차이 그것 까지는 모릅니다. 가성을 쓰는 학생한테 진성이랑 가성을 반반 씩 섞으라고 하는데요? 너 무 가성인 학생한테는 소리의 힘을 더 길러주는 편입니다.
두성도 가성인데 머리 쪽에서 보내다 보니까 가성이라고 하 면은 약간 성대를 더 약간 벌린다고 해야 되잖아요? $(\mathrm{S} 3,16)$

가성은 약간 가짜 소리? 그렇게 좀 생각하고. 두성 같은 경우는 성악가들이 고음을 내거나 할 때 머리 쪽으로 소리 를 좀 울려서 내는 소리라고 생각합니다. 두성보다는 가성 이 조금 성대에 무리가 가지 않을까 저는 생각합니다. 가성 은 아무래도 조금 성대가 세게 부딪힐 것 같습니다. 왜냐하 면 두성을 쓸 때 저는 이제 호흡을 더 많이 쓰고 몸에 힘을 더 빼야 된다고 생각하는데, 가성은 뭐 제가 가성을 내 본 적이 없어 잘 모르겠지만 가성을 낸다고 생각하면 몸을 약 간 더 쓰게 되지 않을까 싶어서 성대에 조금 더 무리가 갈 것 같습니다. (S4, 18-21)

저는 성악가는 두성을 써야 된다고 생각하고 두성이란 말을 써야 되고. 가성은 가짜의 그 가성이란 뜻인데. 저는 성악 하는 사람은 두성, 흉성으로 애기를 해야지.. 가성을 쓰는 걸 별로 애기를 저는 좋아하지는 않는데요. 똑같이 성 대를 잘 쓰고 호흡을 유지한 상태에서 진짜 소리가 나지만 두성, 그러니까 머리 공명을 쓰는 거지. 가성을 쓸 때는 성 대가 굉장히 적은 부분이 마찰이 될 거에요. 그리고 위로 올라가죠. 성대가. (S5, 13-16)

두성과 가성의 차이? 글쎄요... 뭘까요? 제가 답을 들어보 고 싶네요. 제가 오히려.소프라노의 노래 소리를 그게 가성이 라고 해도 무방합니까? 노래할 때 그런 발성법을? $(\mathrm{S} 9,18,19)$

또한, 두성과 비성을 추상적으로 설명하는 경우가 많았는데, 두 성은 비강을 울리거나 이마쪽이나 코 위의 두개강을 울리는 소리 로 표현하거나 복식호흡을 통해 머리를 이용해서 발성하는 것으로 기술하였다.

일단은 가성은 가요나 뮤지컬이나 그런 쪽에서 많이 쓰 고요. 진성으로 두성을 쓰면 소리가 힘있게 전달이 파장을 타고 잘 전달이 잘되죠. 그래서 노래 부르는 그 프레이징도 안 깨지고요. 가성을 쓰다 보면 갑자기 프레이징이 깨집니 다. $(\mathrm{S} 6,22,23)$

바리톤은 passaggio 지점이 미플렛 이거든요? 그러니까 레까지는 두성을 울리게 놔두고 미플렛부터는 이마 약간 중간, 미는 이마 약간 위, $\mathrm{G}$ 정도 되면 정수리까지. 저는 이 렇게 반원을 계속 그러니까 미플렛부터 점점 반원이 각이 넓어지는 거죠. 정수리까지... 그게 그러니까 앞쪽 두성 이 마 쪽 maschera에 걸친 앞쪽 두성을 쓰는 게 진성의 고음이 
라면 falsetto는 연구개로 해서 바로 이렇게 뒤를 쓰는 거죠. 연구개.. 연구개로 바로. 다이렉트로. 그러니까.. 어.. 진성.. 진성의 고음은 찍고 maschera를 찍고 돌리는 거? 반원을 앞으로 이마 쪽으로 돌리는 거면. 돌려서 이제 두성으로 간 다면. 어... 팔세토는 연구개에서 바로 다이렉트로 일직선으 로 위로 올라가는... (S7, 26-28)

두성이라고 하면 실제로는 두성이라는 게 비강을 울리 는 울림 아닙니까? ...(중략)... 그러니까 두성이라는 거 자체 는 그냥 뭐 자꾸 저도 이렇게 두성에 대해서 막 혼돈이 많 이 와서 책도 많이 보고했는데 .. (중략)... 실제적으로 우리 머리에는 뇌가 가득 차 있는데 두성이 가득 찰 수 없고.. 그 게 비강의 울림을 그 앞에 조그맣게 이제 코 위에 있는 조 그만 두개강에 의해서 조금은 울려 주는 그걸 두성이라고 애기하는 거 같습니다(S8, 16,17$)$

두성은 머리를 이용해가지고 gola는 내린 상태에서.. 복 식호흡에 바탕으로 해서 두성 머리 쪽을 이용한 거고요. 가 성은 gola를 끼워 가지고 이용하는 거죠. 두성을 조금 더 추 구를 하고 있습니다. $(\mathrm{S} 10,12,13)$

성종은 성악가의 인생과 음악적 삶에 가장 중요한 첫 결정이라고 볼 수 있는데, 본 연구의 면담자들의 성종은 주로 성악 교사에 의해 결정되었으며, 본인이 부를 수 있는 음역을 고려하여 결정되었다고 보고하였다. 제자들의 성종을 결정할 때에도 귀로 듣고 결정하는 경우가 대부분이었다. 하지만 이들 중에는 성종을 잘못 결정하거나 성종을 항상 고민하는 성악가도 있다고 하였다. 특히, 본 연구에서 는 모든 낮은 음역대의 면담자들이 성악 교사가 바뀜에 따라 성종 이 바뀐 경험을 가지고 있었으며, 잘못된 성종 결정으로 인한 음성 문제와 심리적 어려움을 경험하였다.

거의 본인의 생각으로 진행이 됐고 소리를 내다보니깐 맞 는 repertoire를 접하다 보니깐 음역에 대한 한계점이나 음 역 이상이나 음역 이하의 한계점에 부딪쳤을 때 제 음역을 찾을 수 있었습니다. 제자들의 성종 결정은 파트를 나눠서 여러 가지 곡을 뽑아놓고, 세, 네 곡을 부르게 한 뒤에 귀로 듣고 결정합니다. (성종을 잘못 선택한 성악가를 본 경험 은) 많습니다. 학생들이 더 많았던 것 같고, 성악가는 그 중 에 많았고요. 학생들이 그런 경우를 많이 봤습니다. 바리톤 이 high 바리톤인데 호흡을 잘 못 써서 호흡이나 이런 근력 들을 잘 못 이용해서 소리가 안 나오면서 테너까지도 할 수 있는 친구인 것 같은데 테너를 안 하는 것 같아서... 그리고
테너인 친구가 고음을 못 낸다는 이유만으로 high 바리톤 으로 했는데, 호흡이나 이런 성대를 잘 쓰면 충분히 날 수 있는 친구인데 못하는 경우도 봤습니다(S1, 8-10, 15)

고등학교 때 입시선생님에 의해서... 결정되었습니다. 제 자들의 성종은 음색으로 결정합니다. 성종을 잘못 선택한 성악가를 본 경험은 특별히 없습니다. $(\mathrm{S} 2,11,12)$

여러 레슨 선생님을 통해서 찾게 되었습니다. 이십 대 중 반 정도에 결정된 것 같아요. 제자들은 소리를 들어보고 결 정을 하는데, 학생들이 대부분이 고등학생에서 20 대 초중 반이기 때문에, 아직은 사실은 성종을 결정하기가 아직 섣 부르다고 생각합니다. 성종을 잘못 선택한 성악가를 본 경 험은 있었습니다. 본인은 메조소프라노라고 했는데 연주를 들어봤을 때 전혀 저 음역대의 적합한 소리가 아니고 소프 라노처럼 가벼운 그런 사람도 있었습니다. $(\mathrm{S} 3,9,10)$

석사 때 교수님이 그렇게 알려 주셔서 공부를 했습니다. 성종을 잘못 했다기 보다 항상 고민을 하는 사람들을 봤고, 저도 고민을 한 적이 있고요. (S5, 13, 14)

고등학교 때 레슨 선생님은 테너라고 결정했지만 대학교 에 입학해서 이 음역이 아니다 그랬고 베이스로 하자 해가 지고 파트가 그 때 정해졌고요. 성종을 잘못 선택한 성악가 를 몇 분 봤죠. 대체로 보면 고음 가수들이 저 음역으로 활 동하시는 거 같아요. 테너인데 바리톤으로 활동 한다거나... 여성분들도 제가 몇 번 밨고요. 소 같은 소리, 시커먼 소리가 나와 줘야 메조 소리인데... 지글지글한 소리가 있는데... (S9, $23,25,26)$

저는 고등학교 때는 테너를 하였고요. 대학교 때는 바리 톤으로 졸업을 했습니다. 유학을 나가서 많은 선생님들을 만남으로써 베이스라는 파트를 선택하게 되었습니다. 처음 가르쳤던 선생님이 테너였기 때문에 테너로 갔던 거 같고 요. 고등학교 때 가르쳐 주신 선생님이 바리톤이었기에 바

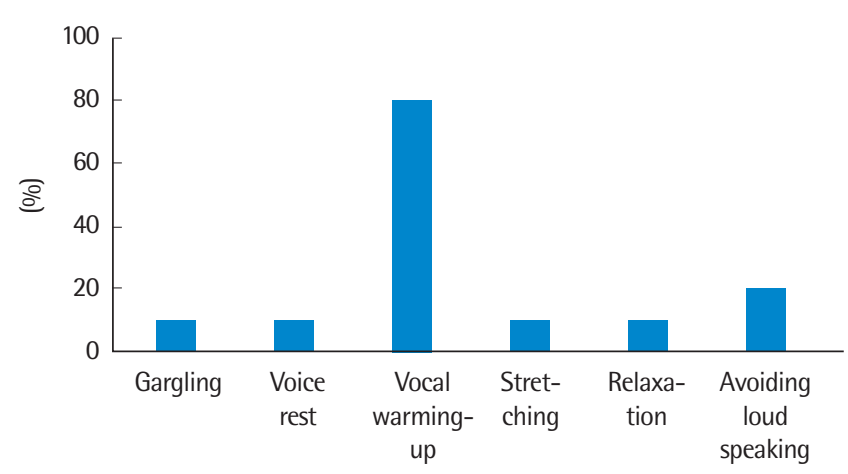

Figure 1. Voice care \& habits in ordinary time in classical singers. 
리톤으로 갔던 거 같습니다. 제자들의 성종은 목소리를 듣 고 학생들의 파트를 정해주고 있습니다. 성종을 잘 못 선택 한 성악가들은 많이 보고 있는 것 같습니다. 바리톤인데 억 지로 테너를 하던지, 테너인데 바리톤을 하던지 종종 보고 있는 것 같아요. 바리톤인데 테너를 하려면 고음을 쥐어짜 야 되니까 항상 컨디션을 타고 항상 힘들어 하는 모습들을 많이 봤고요. 또 테너인데 바리톤을 할 경우 음정은 잘 나 되 또 바리톤의 중후한 음성이 안 나기 때문에 테너에 얇은 음성이 나기 때문에 항상 사람들의 입에 오르내리는 그런 것도... 힘들지 않겠습니까? (S10, 13-15)

면담자 중에는 성대의 길이나 두께와 같이 과학적이고 의학적인 방법으로 결정하는 것을 들어본 적 이 있으나 크게 도움이 되지 않 는다고 보고하였다. 오히려 발성을 귀로 들어보고 음색을 판단하거 나 신체를 보고 결정하는 경우가 많으며, 본인의 경험으로 지각하는 발성의 편안함을 기준으로 결정하는 경우도 있었다.

제가 성악을 중학교 3학년 때 시작을 했는데 그때 선생님 들이 다들 이제 저 보고 소프라노라고 하셔서 소프라노로 활동을 했었는데, 소프라노를 계속 하다 보니까 성대에도 무리도 가고 Balla도 생기고, 그러다 보니까 좀 노래하는데 도 힘들고, 그리고 항상 목이 아프고, 호흡도 제대로 사용 을 못하고 힘들었었는데, 제가 외국을 다니면서 선생님들 을 많이 만나봤을 때 선생님들이 다들 저 보고 소프라노가 아니라 메조가 맞는 것 같다 그러셔서 확실히 메조를 해보 니까 저한테 무리도 가지 않고 제 목소리에도 맞고 제가 편 하게 낼 수 있는 소리여서 메조로 바꾸게 되었습니다. (중 략)... 제자들의 성종 결정은 본인이 갖고 있는 소리에서 편

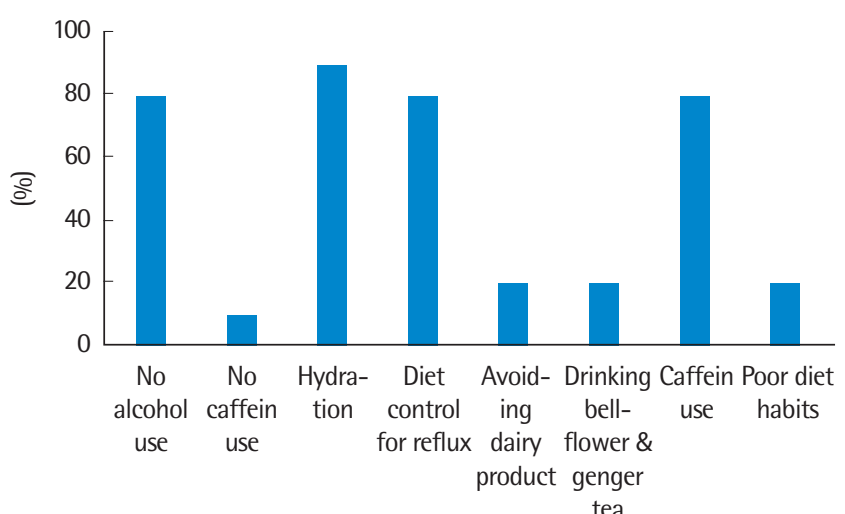

Figure 2. Diet care \& habits in ordinary time in classical singers.
하게 낼 수 있는 부분이 제일 맞는다고 생각합니다. (S4, 10, $11,17)$

제가 고 3때 이제 입시 선생님께서 소리 빛깔을 보고 테 너라고 정해 주셨어요. 제자들의 소리도 직접 소리 빛깔을 듣고 제가 정해주는데요. 성대의 길이와 두께로 성종을 결 정한다는 것은 들어 봤어요. 한국에서 들어 봤는데, 크게 도움이 되지 않는 것 같고요, 제 생각은. 가장 편안한 목소 리로 발성을 했을 때 억지로라도 고음이 나면요, 그 학생은 제가 봤을 때 $90 \%$ 는 다 테너였어요. 억지로라도 고음이 안 나면 그거는 바리톤 입니다. (S6, 25-27)

맨 처음에 레슨 갔더니 (레슨 선생님께서) 그냥 바리톤이 라고 하셨어요. (학생들의 성종 결정은) 발성을 들어보죠. 보통은 몸을 봐도 좀 아는데, 몸을 보면 70퍼센트 알고. 나 머지 확실히 알기 위해서 발성을 해보면 나오죠. 그리고 발 성 해보고 passaggio를 들어보는 거죠. 미플렛 들어보고, 미플렛에서 걸린다? 그러면 바리톤. 성대의 길이와 두께로

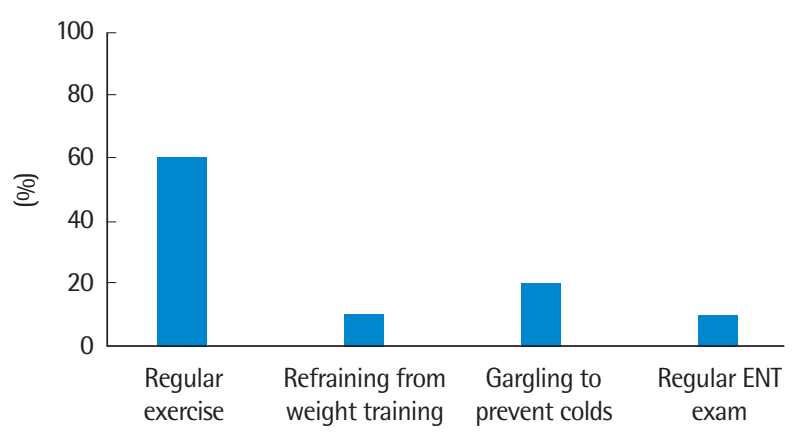

Figure 3. Exercise and other habits in ordinary time in classical singers.

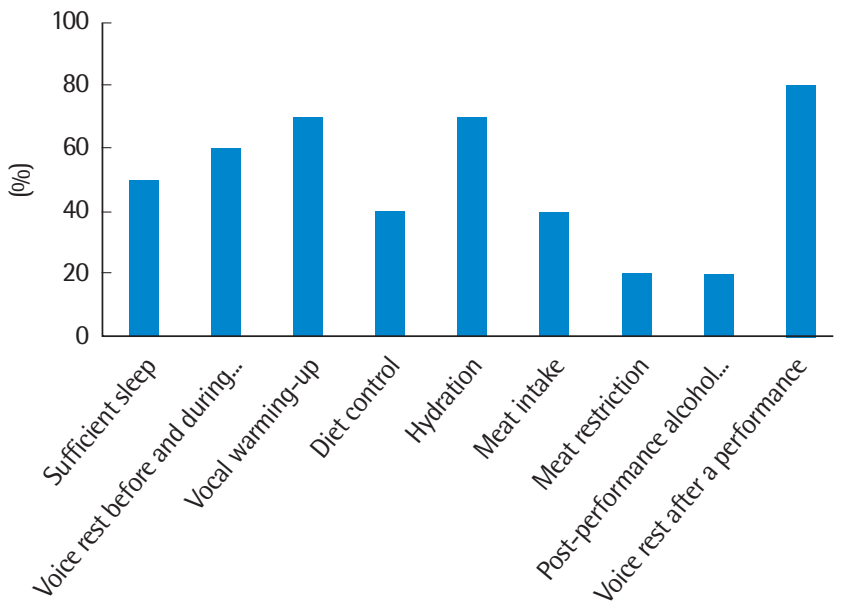

Figure 4. Voice care and diet habits before, during, and after the performance. 
성종을 결정한다는 그 일화는 들었거든요. 이탈리아에 있 을 때. 이게 뭐 어느 정도는 맞겠지만 애매하게 걸쳐 있는 소 리들은 이러나 저러나 할 수 있을 것 같다는... $(\mathrm{S} 7,29,30)$

레슨 선생님에 의해서 그때 당시에는 그렇게 했습니다. 제 자들의 성종 결정은 보통 목소리를 듣고 판단합니다. 성종이 잘못 결정된 경우를 간혹 본 것 같습니다. 독일에서는 그렇 게 합니다..(중략)... 성대 길이와 두께를 재어 가지고 너는 바 리톤이다 테너다 할 수 있는데 (음색의 문제가 있기 때문에) 그게 $100 \%$ 는 아니라고 이야기를 들었습니다. (S8, 20-22)

\section{논의 및 결론}

본 연구는 오페라 가수로 활동하는 전문 성악가 10 명(남성 5 명, 여성 5명)을 대상으로 심층 면담을 통하여 전문 성악가의 음성 사 용 및 관리 및 음성에 관한 지식과 이해에 관한 질적연구를 시행하 였다. 본 면담 결과, 면담자들은 음성장애를 예방하기 위해 공연 전, 중, 후에 철저하게 음성을 관리하고 있는 것으로 나타났다. 공연 이 없는 평상 시에도 몸과 성대의 컨디션을 관리해야 하기 때문에 일상 생활 속에서 지속적으로 음성을 관리하는 것으로 나타났다.

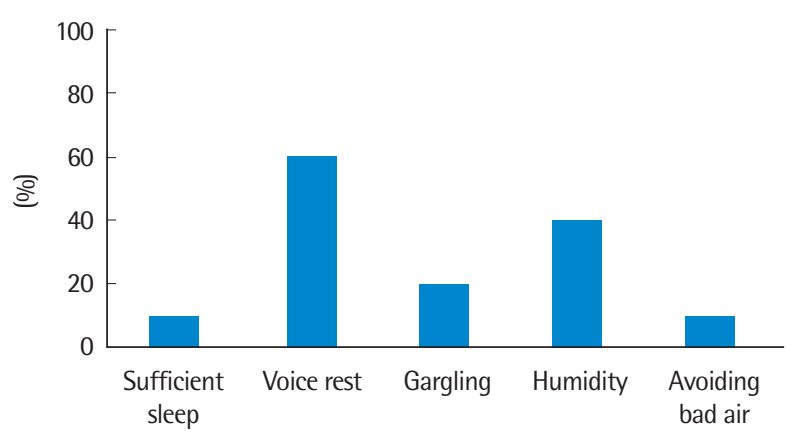

Figure 5. Voice care and habits when throat hurts.

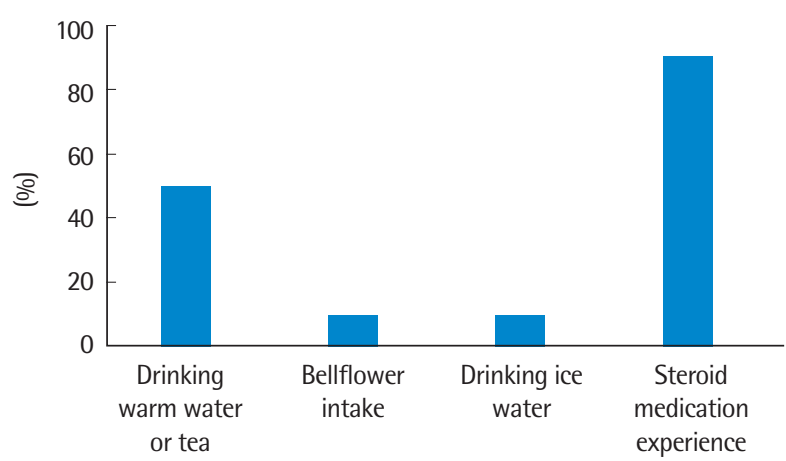

Figure 6. Diet care and medication when throat hurts.
또한, 오랜 기간의 경험적 시행 착오를 통해 알게 된 자신만의 음성 노하우를 가지고 있었으며, 자신의 생각과 경험에 근거하여 음성을 관리하고 행동하는 것으로 나타났다.

첫째, 평상시 음성 사용 습관은 Figure 1에서 보듯이 음성 사용 전에 허밍이나 입술트릴과 같은 발성 워밍업을 하는 습관이 가장 많았고, 음성 휴식(10\%)이나큰 소리로 말하지 않기(20\%), 이완(10\%) 및 스트레칭(10\%), 가글링(10\%)과 같은 음성 관리 습관을 가지고 있는 것으로 나타났다. 한편, 식이 습관과 관련해서는 평상 시에 $90 \%$ 가 하루에 $1.5 \mathrm{~L}$ 이상의 물을 마시려고 노력하는 것으로 나타 났으며, 응답자의 $20 \%$ 가 와인이나 주 $1-2$ 회 정도 알코올을 섭취하 였으나, 응답자의 $80 \%$ 는 위산 역류로 인한 음성 문제를 예방하기 위하여 평상시에도 알코올이나 야식을 자제하였으며, $20 \%$ 는 목에 이물감을 유발하는 유제품도 피하려고 노력하는 것으로 나타났다. 하지만, 응답자의 $80 \%$ 가 커피와 같은 카페인 음료를 섭취하는 것으 로 나타났으며, $20 \%$ 만이 보이차나 생강차 혹은 도라지차와 같은 음 료를 섭취하는 것으로 나타났다(Figure 2). Jin 등(1999)의 설문 연 구에서는 성악도의 $53 \%$ 가 알코올을 주 1-2회 섭취하고, $97 \%$ 가 카 페인 음료를 하루 1-2잔 섭취한다고 보고하였다. 이에 반하여 Santos, Montagner, Bastilha, Frigo와 Cielo (2019)의 연구에서는 대부

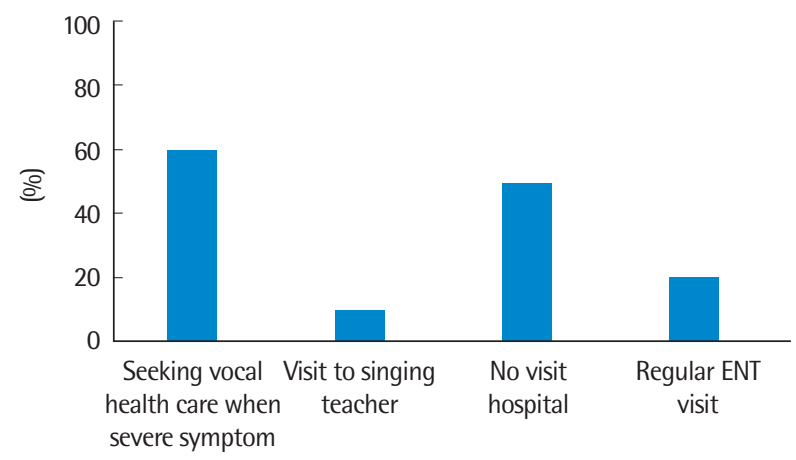

Figure 7. Awareness of medical treatment when throat hurts.

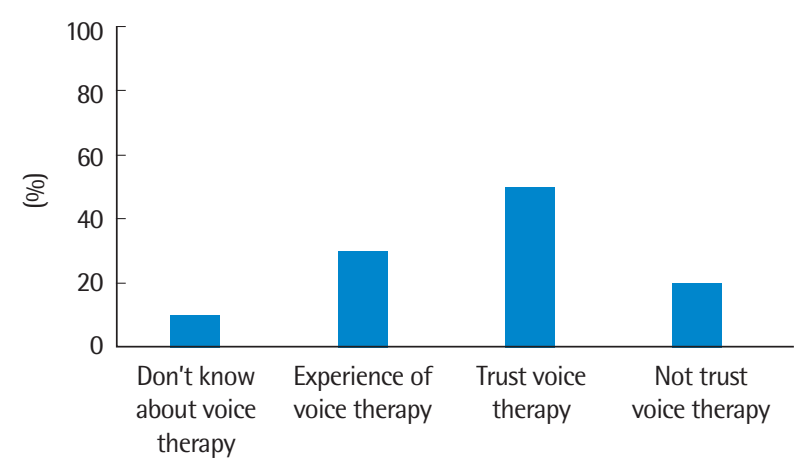

Figure 8. Awareness of voice therapy. 
분의 성악가들이 비흡연자었으며, $77 \%$ 가 알코올을 섭취하지 않는 것으로 나타났다. 또한 실용 음악가들이 클래식 성악가에 비해 알 코올 음료를 더 빈번히 섭취하고 음성을 덜 관리하는 것으로 나타 났다. 본 연구는 클래식 성악가만을 대상으로 하였으나, $80 \%$ 가 알 코올 음료를 섭취하지 않는 것으로 나타나 이전 국내 연구에 비해 클래식 성악가들이 음성에 나쁜 영향을 줄 수 있는 습관을 인지하 는 문화가 확산되고 음성 관리에도 더 높은 관심과 노력을 기울이 는 것으로 해석된다. 그 외에도 평상시에 유산소 운동과 같은 규칙 적인 운동을 통해 건강을 유지하였고, 웨이트 트레이닝과 같은 근 력 운동은 성대에 무리를 주는 운동으로 인지하는 경우도 있었다 (Figure 3).

또한, 위식도역류증은 성악가들에게 빈번히 나타나는 증상인데 이는 적절한 호흡을 위해 필요한 복압의 증가와 공연, 스트레스로 기인한다. Lloyd, Ruddy, Silverman, Lewis와 Lehman (2017)의 연 구에서도 위식도역류 검사에서 성악가의 $95 \%$ 에서 경미한 위식도 역류증이 관찰되었으며, 이는 위식도역류증이 성대 염증을 유발하 여 목소리에 나쁜 영향을 준다고 하였다. 본 연구에서도 성악가들 대부분이 위식도역류증이 목소리에 미치는 영향을 경험하거나 인 지하고 있었으며, 이를 위해 식이 조절에 신경을 많이 쓰는 것으로 나타났다.

둘째, 공연 전·중· 후의 음성 휴식 및 음성 사용 습관에 대한 질 문에 성악가의 $50 \%$ 는 공연 전날 일찍 잔다고 보고하였으며, $60 \%$ 는 공연 전 이완 및 음성사용을 자제하는 반면, $70 \%$ 는 공연 중 호흡 운동이나 입술 트릴이나 허밍으로 발성 워밍업을 한다고 보고하였 으며, 면담자의 $80 \%$ 는 공연 후 충분한 휴식을 가진다고 보고하였 다. 이러한 결과는 면담자의 오랜 음성 사용 습관에 따라 다르게 나 타나지만, 대부분의 면담자들이 공연을 위한 음성 사용 이후에도 계속적으로 음성 관리를 하고 있음을 나타내었다. 공연 전 - 중 - 후 의 식이 습관에 대한 질문에 면담자의 $70 \%$ 가 수분 공급을 매우 중 요시 하는 것으로 나타났다(Figure 4).

셋째, 목이 아플 때 음성 관리는 Figure 5와 같이 음성 휴식이 가 장 높았고, 따뜻한 물이나 차를 섭취하였으며, 스테로이드 복용 경 험도 90\%에 달하였다(Figure 6).

목에 통증이 있을 때 음성 휴식 및 음성 사용 습관에 대한 질문 에 면담자의 $60 \%$ 는 주로 음성 휴식을 취하였으며, $40 \%$ 는 수분을 많이 섭취하였다. 이외에 도라지 차나 따뜻한 꿀 차와 같은 것을 마 신다고 보고하였다. 본 연구에 참여한 면담자들은 목이 심하게 아 플 경우나 소리가 나지 않을 경우에 $60 \%$ 가 병원을 방문하여 의학 적 진단이나 도움을 받았으며, $50 \%$ 는 목이 아파도 병원을 가지 않 고 쉬거나 스스로 음성 관리를 오랫동안 해온 경험을 바탕으로 병
원 방문을 자제하는 경향이 있었다. 성악가의 $10 \%$ 는 성악 교사를 찾아가 발성 교정을 받기도 하였고, $20 \%$ 는 정기적으로 이비인후과 를 방문하여 성대를 점검하는 것으로 나타났다(Figure 7). 또한, 면 담자의 $10 \%$ 는 음성 치료에 대해 알지 못하였으며, $30 \%$ 는 음성 치 료를 받았던 경험이 있었다. 50\%는 음성언어치료사의 음성 치료가 성악가의 발성 문제를 해결할 수 있다고 신뢰하였으며, $20 \%$ 는 신뢰 하지 않는 것으로 나타났다(Figure 8). 하지만, 약물요법이나 수술 적 처치 이외에도 성대를 확인하고 그에 대한 자세한 설명과 유의 점을 제공할 수 있는 언어치료사의 도움을 필요로 하고 있음을 알 수 있다. 따라서, 객관적이고 표준적인 검사 결과를 토대로 효과적 인 성악 발성이나 발화 음성에 대한 음성 치료 및 재활에 대한 인식 및 신뢰가 필요한 것으로 나타났다.

Petty (2012)의 연구에 의하면, 성악가들은 음성 문제가 있음에 도 불구하고 의료적 처치를 받는 것을 주저하는 것으로 나타났으 며, 의학적 치료의 도움을 받기보다는 가정에서 처치하는 경향이 8 배나 높았다. Gunjawate, Aithal, Guddattu, Kishore와 Bellur (2015) 은 인도의 클래식 성악가들을 대상으로 음성 문제와 관련된 태도 에 대한 조사에서 $70 \%$ 의 성악가들이 음성과 관련된 문제가 생겼 을 때 일주일 간 기다려 보거나 전문가의 도움을 받지 않는 것으로 나타났으며, $30 \%$ 만이 문제가 발생한지 일주일 내에 전문가의 진찰 을 받는 것으로 보고하였다. 이러한 결과는 성악가들의 의료적 처 치에 대한 인식 부족, 부적절한 정보, 재정적 장벽, 의료적 처치에 대한 두려움 등이 원인이라고 하였다. Gilman, Merati, Klein, Hapner 그리고 Johns (2009)의 연구에서도 가수들이 자신의 목소리에 매우 의존하면서도 목소리에 문제가 생겼을 때 응답자의 $41 \%$ 가 의 학적 진료를 받지 않는다고 응답하였으며, Weekly 등(2018)의 설문 연구에 따르면, 음성 병변이 생기면 응답자의 $48 \%$ 는 이비인후과를 내원하고, $46 \%$ 는 자가 음성 휴식을 취하며, $39 \%$ 는 레슨 선생을 찾 아가 음성 개선을 위해 노력한다고 보고하였다. 응답자들이 의학 적 치료를 받지 않는 이유는 증상의 완화, 증상 완화 예상, 자가 완 화 가능, 경제적 문제, 치료의 불편함 등의 순서로 나타났다. Weekly 등(2018)의 연구 결과와 비교하여 볼 때, 본 연구의 면담자들이 더 내원을 하지 않는 것으로 나타났다. 면담자의 $20 \%$ 만이 즉시 병 원을 방문하였고, $60 \%$ 는 목의 증상이 심각한 경우, 즉 음성 휴식을 통해 목 상태가 개선이 되지 않는 경우에 병원을 방문한다고 보고 하였다. 감기가 걸렸을 경우에만 병원을 방문하여 의학적 도움을 받았으며, 노래로 인해 목이 아플 때는 병원 대신 성악 교사를 방문 하거나 통상적으로 집에서 쉬면서 관리한다고 보고하였다. 이러한 병원에 대한 거부감은 오랜 시간 비슷한 병변을 겪고 얻게 된 노하 우가 있거나, 혹은 약물과 병원 처방이 오히려 일시적인 음성 악화 
와 성대 건조함을 야기한다고 믿는 고정 관념 때문이었다. 콧물, 기 침, 가래를 완화시키기 위한 약은 성대를 건조하게 할지도 모르지 만 음성의 초기 병변을 조기에 발견하여 적절한 시기에 치료를 받 는 것이 가장 음성 문제를 해결할 수 있는 최선의 방법일 것이다. 따 라서, 전문 성악가들은 음성 문제를 예방하고 관리하기 위해서 정 기적인 성대 검사가 반드시 필요하고, 병원과 의학적 처방에 대한 부정적 고정 관념이나 인식을 개선해야 할 필요가 있다. 또한, 국내 의 성악가들을 대상으로 한 설문 연구에 따르면, 음성치료를 받은 경험이 있는 경우는 7명(5.5\%)인 반면, 음성치료를 받은 경험이 없 는 경우는 121 명(94.5\%)로 성악가의 대부분이 음성치료에 대한 경 험이 적은 것으로 나타났다. 또한, 흥미로운 것은 음성 문제의 원인 이 '과도한 대화'가 $33 \%$ 로 가장 많았고, '노래 연습과 고함'은 $20 \%$, 기타 '목이 약함'은 13\%, ‘수술' 6\%, '모름' 7\%로 응답하였다.(Kang et al., 2018). 따라서, 성악가의 음성 문제의 원인이 노래와 관련된 문제보다는 대화와 같은 말소리 문제로 나타남을 알 수 있다. 그러 므로, 음성치료는 성악가들의 이러한 음성 문제의 원인을 중재하 고 예방하는 데 도움을 줄 수 있을 것이다. 아울러, 성악가의 음성 문제를 바로 노래하기나 가창으로 평가하기 보다는 먼저 동일한 노 래를 낭독하거나 말하듯이 하게 하여 평가하는 것이 중요하며, 말 하는 단계에서 음성 문제를 발견하여 이를 수정하고 노래조로 말 하기, 가창하기로 확장하여 중재하는 것이 필요할 것이다.

넷째, 성악가들은 훈련 받지 않은 일반인에 비해 음역, 후두 위치, 성대 접촉율, 음성 강도에서 차이가 있는 것으로 나타났는데(Awan, 1991; Choi, Nam, Kim, Kim, \& Choi, 2006; Chung, 1998, 1999; Howard, Lindsey, \& Allen, 1990; Ship, 1987), 이는 좀 더 세련된 발 성법을 습득하는 동안 발성 산출의 해부 및 발성 메커니즘에 관한 생리학적 지식들이 증가할 것이라고 추측할 수 있다. Braun-Janzen 과 Zeine (2008)의 연구에서는 전문적 성악가들이 아마추어 성악 가에 비해 더 높은 수준의 발성 해부 및 생리학적 지식을 가졌다고 보고하였으며, 음성장애 치료에 있어서 언어재활사의 역할을 더 잘 이해하고 있는 것으로 나타났다. 이와는 반대로 최근 Ewelina, Ewa, Maria, Ewa 그리고 Kazimierz 등(2017)의 한 연구에 따르면, 성악 가의 대부분이 성도(vocal tract)에 관한 해부 및 생리에 대한 지식 이 유용하다고 응답하였으나, 실제로 응답자의 $75 \%$ 가 해부 및 생 리에 대한 지식이 약하거나 불충분한 것으로 나타났다. 하지만, 본 연구에서는 각 면담자에게 발성의 기관과 산출에 대해 질문한 결 과, 발성에 관여하는 신체 기관의 해부학적 지식에 대한 정보가 부 족하였고 잘못 인식하고 있는 경우도 많이 나타났다. 또한, 들숨 시 횡격막의 변화, 복식 호흡 시 복부의 변화, 발성 시 호흡의 패턴, 들 숨 시 후두의 위치와 같은 노래 시 음성 산출의 메카니즘 및 가창
시 성구(register)에 대한 질문에 대해 면담자들은 다양한 의견과 생각을 나타내었다. 일반적으로 성악가들은 추상적인 설명으로 학 습하고 지도하는 경우가 많으며, 거의 대부분의 대학교 이상의 성 악과에 음성학이나 음성 해부나 생리에 대한 교과목이 개설되어 있지 않으므로 과학적이고 의학적인 지식 수준이 낮을 수 있다. 또 한, 본 연구의 면담자들은 이태리어 용어를 사용하여 설명하는 경 향이 많이 나타났는데, 예를 들면, Balla는 사전적 의미로 '춤추다 (to dance)'라는 뜻의 Ballare의 줄임말로, 성악가들은 불규칙적이 거나 빠른 vibrato를 칭하며, Appoggia는 '지지하다(to support)'라 는 뜻의 Appoggiare의 줄임말로, '호흡을 지지하다' 또는 '받치다' 라는 의미로 사용된다. Maschera는 '안면(mask)'이라는 뜻으로, 비 강 공명을 위해 얼굴 광대뼈를 뜻하며, Gola는 '목(throat)'이라는 뜻으로, 통상적으로 '후두'의 의미로 사용된다. 이처럼 전세계적으 로 성악가들은 이태리의 유학 경험과 상관없이, 음성 산출 및 발성 테크닉을 이태리어 단어로 사용하는 경향이 있다. 이는 성악이라 는 학문이 200년 이상 추상적인 설명으로 교수하고 학습해 왔기 때 문이며, 음성에 대한 과학적인 교육이나 지식 없이, 성악의 본고장 인 이태리 유학파 스승들에게 구전된 테크닉을 습득했기 때문이 다. 성악가들은 어릴 때부터 성악 교사의 말을 통하여 이태리어 단 어들을 사용하여 성악을 배우며, 성악 교사들은 어느 정도 이해는 하고 있지만 말로는 설명할 수 없는 용어들의 의미를 제자들에게 전달하며 가르친다. 따라서, 이러한 용어들을 체계적이며 과학적으 로 설명할 수 있도록 근거 기반의 이론과 실제가 병행되어야 하며, 이를 토대로 성악 용어를 구체화하고 재정립하는 것이 필요하다.

또한, 각 면담자에게 성종 결정 뿐만 아니라 제자들의 성종 결정 에 대해 인터뷰한 결과, 면담자들은 다양한 의견과 생각을 나타내 었다. 면담자의 $90 \%$ 가 성악 교사에 의해 결정되었으며, $60 \%$ 는 제 자들의 성종을 귀로 듣고 결정해 준다고 보고하였다. 그러나 면담 자의 $50 \%$ 가 잘못된 성종 결정으로 판단되는 성악가들을 본 경험 이 있다고 보고하였는데, 이는 비과학적이고 주관적인 성악 교사의 결정에 따른 오류가 있을 수 있다는 것을 시사한다. Nam, Paik과 Choi (2007)의 클래식 성악가들의 성종에 관한 연구에 의하면, 성 종은 경험이 많은 성악 교사들의 경험적 판단에 의해 음역과 음색 의 말소리 높이 등 오랜 발성 교육 경험에 의해 판단된다고 하였다. 하지만 이러한 경험적 판단이 주관적이며 개인적 선호도에 영향을 미치므로 오류를 줄이기 위해서는 기본주파수 측정, 후두부의 크 기, 성대의 두께 및 길이, passagio하는 음의 높이 등을 종합적으로 고려하여 음성 클리닉을 방문하여 전문 음성인의 도움을 받아 성 종을 결정하도록 제안하였다. 본 연구의 결과를 종합해 볼 때, 전문 성악가들은 발성 기전에 관한 해부 및 생리 지식이 부족하였으며, 
잘못된 개념을 가지고 있는 경우도 있었는데, 이러한 결과는 음성 치료사들이 전문 성악가들에게 발성 기전이나 음성 오남용이 성대 에 미치는 영향에 대해 설명해 줌으로써 성악가들에게 유용한 정 보를 제공해 줄 수 있을 것이다. 또한, 음성언어치료사의 역할에 대 해 낮은 인식이 보고되었는데, 음성언어치료사들은 성악가와 좀 더 적극적으로 대화하고 이해하는 기회를 극대화하여 성악가의 음 성장애를 예방하고 건강한 음성을 유지하는 데 도움을 줄 수 있을 것이다.

\section{REFERENCES}

Awan, S. N. (1991). Phonetographic profiles and F0-SPL characteristics of untrained versus trained vocal groups. Journal of Voice, 5(1), 41-50.

Braun-Janzen, C. \& Zeine, L. (2008). Singers' interest and knowledge levels of vocal function and dysfunction: survey findings. Journal of Voice, 23(4), 470-483.

Carroll, T., Nix, J., Hunter, E., Emerich, K., Titze, I., \& Abaza, M. (2006). Objective measurement of vocal fatigue in classical singers: a vocal dosimetry pilot study. Otolaryngology \& Head Neck Surgery, 135(4), 595-602.

Choi, S. H., Nam, D. H., Kim, D. W., Kim, Y. H., \& Choi, H. S. (2006). Characteristics of phonatory and respiratory control on pitch, loudness, register change in untrained and trained singers. Journal of the Korean Society of Logopedics, Phoniatrics, \& Logopedics, 17(2), 115-126.

Chung, S. M. (1998). Vocal efficiency measures in classically trained western signers. The Journal of the Korean Society of Logopedics and Phoniatrics, 9(1), 43-46

Chung, S. M. (1999). Acoustic analysis of classically trained western singers. The Journal of the Korean Society of Logopedics and Phoniatrics, 10(2), 124 129.

Cleveland, T. F. (1994). An overview of laryngeal function in different singing styles. Journal of Singing, 51, 37-38.

Ewelina, S. B., Ewa, O.W., Maria, S., Ewa, K., \& Kazimierz, N. (2017). Singers' vocal function knowledge Levels, sensorimotor self-awareness of vocal tract, and impact of functional voice rehabilitation on the vocal function knowledge and self-awareness of vocal tract. Journal of Voice, 31(1), 122. e17-122.e24.

Garcia, M. G., \& Lopez, J. M. (2017). Voice habits and behaviors: voice care among flamenco singers. Journal of Voice, 31(2), 246.e11-246.e19.

Gilman, M., Merati, A. L., Klein, A. M., Hapner, E. R., \& Johns, M. M. (2009). Performer's attitudes towards seeking health care for voice issues: under- standing the barriers. Journal of Voice, 23(2), 225-228.

Gunjawate, D. R., Aithal, V. U., Guddattu, V., Kishore, A., \& Bellur, R. (2015). Exploring attitudes of Indian classical singers toward seeking vocal health care. Journal of Voice, 30(6), 761.e23-761.e26.

Howard, D., Lindsey, G., \& Allen, B. (1990). Toward the quantification of vocal efficiency. Journal of Voice, 4(3), 205-212.

Jeon, B. H., Kim, Y. R., \& Yoo, J. Y. (2018). The study of the singing voice handicap index for Korean soprano singers. Journal of Speech-Language \& Hearing Disorders, 27(3), 55-63.

Jin, S. M., Kim, D. Y., Ban, J. H., Lee, S. H., Song, Y. K., Kwon, K. H., Lee, K. C., \& Lee, Y. B. (1999). Problems of strobovideolarygoscopic findings and usual voice management of vocal major students, and acoustic characteristics of dinging voice. The Journal of the Korean Society of Logopedics and Phoniatrics, 10(1), 43-49.

Kang, H. N., Kim, S. H., \& Yoo, J. Y. (2018). Voice hygiene habits and the characteristics of Korean Voice-Related Quality of Life (K-VRQOL) among classical singers. Phonetics and Speech Sciences, 10(3), 49-59.

Kim, Y. R., \& Yoo, J. Y. (2017). A literature review of Korean classical singers' voices. Journal of Speech \& Hearing Disorders, 26(1), 33-46.

Leah, M. \& Jayme, D. (2018). Identifying knowledge gaps in clinicians who evaluate and treat vocal performing artists in college health settings. Journal of Voice, 32(3), 385E7-385E15.

Lee, H. N., \& Yoo, J. Y. (2016). The effect of Vocal Aerobic Treatment on classical singer. Proceedings of the 2019 conference of the KASA \& KSHA, $72-75$.

Lloyd, A. T., Ruddy, B. H., Silverman, E., Lewis, V. M., \& Lehman, J. J. (2017). Quantifying laryngopharyngeal reflux in singers: perceptual and objective findings. BioMedical Research International, 1-10.

Moon, Y. I., \& Chung, S. M. (1998). The analysis of voice problems in Korean classical singers. Korean Journal of Otolaryngology-Head and Neck Surgery, 41(9), 1194-1198.

Nam, D. H., Paik, J. Y., \& Choi, H. S. (2007). Voice classification of trained classic singers. Journal of the Korean Society of Logopedics, Phoniatrics, \& Logopedics, 18(1), 56-61.

Petty, B. E. (2012). Health information seeking behaviors among classically trained singers. Journal of Voice, 26(3), 330-335.

Pyo, H. Y. (2011a). A qualitative study on voice use and evaluation of professional voice user patients. Korean Journal of Communication \& Disorders, 16(3), 346-359.

Pyo, H. Y. (2011b). A qualitative study on voice therapy for professional voice 
Sang Hee Park, et al. • Qualitative Study on the Voice care and knowledge in Singers

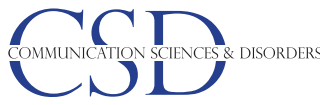

users. Korean Journal of Communication \& Disorders, 16(4), 437-448.

Phyland, D. G., Oates, J., \& Greenwood, K. M. (1999). Self reported voice problems among three groups of professional singers. Journal of Voice, 13(4), 602-611.

Santos, S. S., Montagner, T., Bastilha, G. R., Frigo, L. F., \& Cielo, C. A. (2019) Singing style, vocal habits, and general health of professional singers. International Archives of Otorhinolaryngology, 23(4), 445-450.

Ship, T. (1987). Vertical laryngeal position: research findings and application for singers. Journal of Voice, 1(3), 217-219.
Shin, Y. J. (2004). A study of singers' voice disorders and voice therapy. The Music Research, 32, 101-136.

Tepe, E. S., Deutsch, E. S., Sampson, Q., Lawless, S., Reilly, J. S., \& Sataloff, R. T. (2002). A pilot survey of vocal health in young singers. Journal of Voice, 16(2), 244-250.

Weekly, E. M., Carroll, L. M., Korovin, G. S., \& Fleming, R. (2018). A vocal health survey among amateur and professional voice users. Journal of Voice, 32(4), 474-478. 


\section{국문초록}

\section{전문성악가의 공연과 관련된 음성 관리, 음성문제 및 음성 지식에 대한 질적연구}

박상희 ${ }^{1,2} \cdot$ 최성희 ${ }^{1,3}$

${ }^{1}$ 대구가톨릭대학교 일반대학원 언어청각치료학과, ${ }^{2}$ 경주대학교 음악예술학부, ${ }^{3}$ 대구가톨릭대학교 바이오메디대학 언어청각치료학과

배경 및 목적: 성악가들은 공연을 위해 자신의 목소리를 건강하게 유지하기 위해 노력하는 엘리트 음성 사용자들이지만, 음성 문제의 위험성이 높다. 전문 성악가들의 음성 관리와 목소리에 대한 지식의 이해는 그들의 음성 관리를 교육하고 일상 활동과 공연에 지장을 줄 수 있는 음성장애를 예방하는 기초가 된다. 본 연구의 목적은 성악가들의 공연 및 음성장애와 관련된 음성 관리 실태와 음성 지식 정도에 대해 살펴보고자 한다. 방법: 오페라 가수로 활동하며 주 5 시간 이상 음성을 전문적으로 사용하는 10 년 이상의 클래식 가수(남 자 5 명, 여자 5 명)가 인터뷰에 참여했다. 인터뷰가 끝난 뒤 인터뷰 내용은 무작위로 선정해 코딩했고 나머지 녹취록은 2 명의 언어재활사 에 의해 코딩되었다. 결과: 인터뷰 결과 상위 4 개 주제와 하위 10 개 주제가 도출되었다: 평상 시 및 공연 전, 도중, 그리고 공연 후의 음성 관리 및 습관(음성 사용 습관, 식이요법 습관, 운동)과 목이 아플 때 음성 관리, 음성 해부학 및 생리학 지식뿐만 아니라 음성장애 시 의 학적 관리 및 음성 치료에 대한 인식이었다. 논의 및 결론: 본 연구 결과, 전문적인 성악가들은 항상 목소리를 관리하려고 노력하였다. 하지만, 목소리 문제가 발생했을 때 개인적인 경험이나 성악교사에 의존하는 것으로 나타났다. 또한, 성악가들은 음성 해부학 및 생리 학에 대한 지식이 부족하였고 음성 치료 경험이 거의 없었다. 음성 위생과 음성 건강 교육은 성악가의 음성 문제를 예방하고 건강한 말 과 성악음성을 유지하는데 유용할 것이다.

핵심어: 음성 관리, 음성 지식, 음성장애, 음성 치료, 성악가, 질적연구

\section{참고문헌}

강하늘, 김선희, 유재연 (2018). 성악가의 음성위생 습관과 한국어판 음성관련 삶의 질(K-VRQOL) 특성. 말소리와음성과학, 10(3), 49-59.

김유리, 유재연 (2017). 국내 성악가 음성에 대한 문헌연구. 언어치료연구, 26(1),33-46.

남도현, 백재연, 최홍식 (2007). 성악가의 성종 구분에 대한 문헌적 고찰. 대한음성언어의학회지, 18(1), 56-61.

문영일, 정성민 (1998). 한국 성악인에서 발생된 음 성 문제 분석. 대한이비인후과학회지-두경부외과학, 41(9), 1194-1198.

신영자 (2004). 성악인의 음성 장애와 치료. 음악연구, 32, 101-136.

이하나, 유재연 (2016). VAT를 활용한 성악가 음성치료 효과. 제 5 회 한국언어청각임상학회.한국언어치료학회 공동학술대회, 72-75.

전불희, 김유리, 유재연 (2018). 한국 소프라노 성악가의 가수음성장애지수 연구. 언어치료연구, 27(3), 55-63.

정성민 (1998). 서양음악을 전공으로 하는 성악인에서의 음성효율 측정. 대한음성언어의학회지, 9(1), 43-46.

정성민 (1999). 서양음악을 전공으로 하는 성악인의 음향학적 분석. 대한음성언어의학회지, 10(2), 124-129.

정성민 (2000). 성악 훈련을 받은 성악인에서의 Voice Range Profile. 대한음성언어의학회지, 11(1), 69-75.

진성민, 김대영, 반재호, 이상혁, 송윤경, 권기환, 이경철, 이용배 (1999). 성악도들의 음성관리 및 성대화상술상의 문제점과 발성에 대한 음향분석학

적 특징. 대한음성언어의학회지, 10(1), 43-49.

최성희, 남도현, 김덕원, 김영호, 최홍식 (2006). 성악가와 훈련받지 않은 일반인의 음도, 강도, 성구 변화 시발성 및 호흡조절 특성. 대한음성언어의학 회지, 17(2), 115-126.

표화영 (2011a). 직업적 음성사용인의 음성문제에 대한 질적 연구(1): 음성사용 실태와 음성평가. 언어청각장애연구, 16(3), 346-359.

표화영 (2011b). 직업적 음성사용인의음성에 대한 질적 연구(2): 음성치료. 언어청각장애연구, 16(4), 437-448.

\section{ORCID}

박상희(제1저자, 교수 https://orcid.org/0000-0002-6936-3390); 최성희(교신저자, 교수 https://orcid.org/0000-0003-2365-6187) 